\title{
A strong east-west Mediterranean divergence supports a new phylogeographic history of the carob tree ( Ceratonia siliqua, Leguminosae) and multiple domestications from native populations
}

Juan Viruel, Nicolas Le Galliot, Samuel Pironon, Gonzalo Feliner, Jean-Pierre Suc, Fatma Lakhal-Mirleau, Marianick Juin, Marjorie Selva, Magda Bou, Dagher Kharrat, et al.

\section{To cite this version:}

Juan Viruel, Nicolas Le Galliot, Samuel Pironon, Gonzalo Feliner, Jean-Pierre Suc, et al.. A strong east-west Mediterranean divergence supports a new phylogeographic history of the carob tree ( Ceratonia siliqua, Leguminosae) and multiple domestications from native populations. Journal of Biogeography, Wiley, 2020, 47 (2), pp.460-471. 10.1111/jbi.13726 . hal-02305921

\section{HAL Id: hal-02305921}

https://hal-amu.archives-ouvertes.fr/hal-02305921

Submitted on 4 Oct 2019

HAL is a multi-disciplinary open access archive for the deposit and dissemination of scientific research documents, whether they are published or not. The documents may come from teaching and research institutions in France or abroad, or from public or private research centers.
L'archive ouverte pluridisciplinaire HAL, est destinée au dépôt et à la diffusion de documents scientifiques de niveau recherche, publiés ou non, émanant des établissements d'enseignement et de recherche français ou étrangers, des laboratoires publics ou privés. 


\section{A strong east-west Mediterranean divergence supports a new phylogeographic history of the carob tree (Ceratonia siliqua, Leguminosae) and multiple domestications from native populations}

Authors: Juan Viruel ${ }^{1,2}$, Nicolas Le Galliot ${ }^{1}$, Samuel Pironon ${ }^{2}$, Gonzalo Nieto Feliner ${ }^{3}$, Jean-Pierre $\mathrm{Suc}^{4}$, Fatma Lakhal-Mirleau ${ }^{1}$, Marianick Juin ${ }^{1}$, Marjorie Selva ${ }^{1}$, Magda Bou Dagher Kharrat ${ }^{5}$, Lahcen Ouahmane $^{6}$, Stefano La Malfa ${ }^{7}$, Katia Diadema ${ }^{8}$, Hervé Sanguin ${ }^{9,10}$, Frédéric Médail ${ }^{1}$, Alex Baumel ${ }^{1 *}$

${ }^{1}$ Institut Méditerranéen de Biodiversité et d'Ecologie marine et continentale (IMBE), Aix Marseille Univ, Avignon Université, CNRS, IRD, Faculté des Sciences et Techniques St-Jérôme, Av. Escadrille Normandie Niémen, 13397 Marseille cedex 20, France

${ }^{2}$ Royal Botanic Gardens, Kew, Richmond, Surrey, TW9 3DS, United Kingdom

${ }^{3}$ Real Jardín Botánico (CSIC), Plaza de Murillo 2, 28014 Madrid, Spain

${ }^{4}$ Sorbonne Université, CNRS-INSU, Institut des Sciences de la Terre Paris, ISTeP UMR 7193, 75005

Paris,France

${ }^{5}$ Laboratoire Biodiversité et Génomique Fonctionnelle, Faculté des Sciences, Université Saint-Joseph, Campus Sciences et Technologies, Mar Roukos, Mkalles, BP: 1514 Riad el Solh, Beirut 1107 2050,

Lebanon

${ }^{6}$ Université Cadi Ayyad Marrakech, Faculté des Sciences Semlalia, Laboratoire d'Ecologie et Environnement, Morocco

${ }^{7}$ Università degli Studi di Catania, Dipartimento di Agricoltura, Alimentazione e Ambiente (Di3A)

Via Valdisavoia 5 - 95123 Catania - Italy

${ }^{8}$ Conservatoire Botanique National Méditerranéen de Porquerolles (CBNMed), 34 avenue Gambetta, 83400 Hyères, France

${ }^{9}$ CIRAD, UMR BGPI, F-34398 Montpellier, France

${ }^{10}$ CIRAD, UMR LSTM, F-34398 Montpellier, France

*Author for correspondence: alex.baumel@imbe.fr 


\begin{abstract}
Aim: Phylogeography of fruit trees is challenging due to the recurrent exchanges between domesticated and wild populations. Here we tested the eastern refugium hypothesis (ERH) for the carob tree, Ceratonia siliqua, which supports its natural and domestication origins in the Eastern Mediterranean and a feral origin in the West.
\end{abstract}

Location: Mediterranean basin

Taxon: Ceratonia siliqua L., Leguminosae

Methods: A phylogenetic reconstruction based on two nuclear and one plastid sequences was performed to estimate the divergence time between the carob tree and its sister species, Ceratonia oreothauma. Variation from four plastid regions and 17 nuclear microsatellite loci were used to decipher genetic structure in the carob tree and to test coalescent-based models by an Approximate Bayesian Computation (ABC) approach. We assessed our hypotheses by examining palaeobotanical records and hindcasting the past distribution of the carob tree at the Mid-Holocene, Last Glacial Maximum (LGM) and Last Interglacial (LIG) using species distribution modelling (SDM).

Results: The split between $C$. oreothauma and $C$. siliqua was estimated at $6.4 \mathrm{Ma}$, and a first divergence within $C$. siliqua at $1.3 \mathrm{Ma}$. After a presence since the Oligocene, Ceratonia was found in the Western and the Eastern Mediterranean in the fossil records during the Pleistocene. Plastid and nuclear markers, characterized by low allelic richness, revealed a strong west-east genetic structuring. Approximate Bayesian computation (ABC) analyses rejected the ERH.

Main conclusions: Our study supports a severe population decline during LIG. The strong west-east divergence and the occurrence of four lineages within $C$. siliqua provided support for a new hypothesis of multiple domestications of the carob tree from native populations throughout the Mediterranean basin.

Key words: Approximate Bayesian computation ABC, carob, coalescence, domestication, origin, palaeobotany, phylogeography, species distribution modelling. 


\section{Introduction}

Phylogeography and palaeobotany have greatly contributed to our knowledge on species evolutionary histories and their ecological responses to environmental changes (Hu et al., 2009). Range contractions and expansions due to the climatic oscillations during the Pleistocene have been reported in temperate tree species (Gavin et al., 2014) as well as in thermophilous Mediterranean trees (Nieto-Feliner 2014; Migliore et al., 2018). The natural distribution ranges of the latter were also influenced by the cradle of several human societies that intensively modified forests due to forage, fruit harvesting or clearing for agriculture (Quézel \& Médail 2003). The domestication of fruit trees began ca. 6,000 years ago in the Eastern Mediterranean and entailed recurrent exchanges between crops and their wild relatives (Meyer et al., 2012; Zohary \& Hopf 2012).

Among the Mediterranean fruit trees, the carob (Ceratonia siliqua L., Leguminosae) is an evergreen dioecious tree characteristic of thermophilous vegetations (Zohary 2002; Quézel \& Médail 2003; Baumel et al., 2018). It has been widely exploited since antiquity, and it is currently used for industrial, agricultural and soil restoration purposes. During its domestication, genotypes with larger and sweeter fruits have been selected and propagated by grafting (Zohary 2002). Despite its economic and cultural importance in the Mediterranean and the long-standing interest of botanists (e.g. de Candolle 1883), the status of the carob tree as a native species of the West Mediterranean vegetation is still source of debate (Ramon-Laca \& Mabberley 2004; Baumel et al., 2018) and a phylogeographic study was still pending.

The genus Ceratonia has been present in the Mediterranean for millions of years and scattered occurrences from the Oligocene to the Pliocene suggest a large ancestral distribution (e.g. Palamarev 1989) followed by a strong decline due to Pleistocene climate changes (Ramon-Laca \& Mabberley 2004). Archaeological, historical and philological evidences suggest a westward human-driven dissemination of C. siliqua (reviewed in Ramon-Laca \& Mabberley 2004). This widely accepted "eastern refugium hypothesis" (ERH) postulates a single eastern refugium and a human-driven dissemination concomitant with its domestication based on three arguments. First, the discovery of a closely related species co-occurring with the carob in Yemen, C. oreothauma Hillc., G.P.Lewis \& Verdc. (Hillcoat et al., 1980), suggests a center of origin in the Arabian Peninsula (Zohary 2002). Second, pollen and macro-remain records support the existence of $C$. siliqua in the East at the end of the Pleistocene and Early Holocene (Zohary 2002); meanwhile studies suggesting its presence in the western part of the Mediterranean during the Pleistocene are less abundant (Brenac 1984; Zapata et al., 2013; Servera-Vives et al., 2018). Third, the western scarcity of local names attributed to the carob tree would also be consistent with a domestication origin in the East (de Candolle 1883; Zohary 2002; Ramon-Laca \& Mabberley 2004). Carob tree cultivars are exclusively propagated by grafting (Zohary 2002) and therefore the history of its cultivation is closely related to the development of grafting methods ca. 3,000 years ago (Meyer et al., 2012). According to the ERH, wild carob populations in the Western Mediterranean would have a recent and feral origin. The ERH, if valid, would be supported by a phylogeographic pattern in which western populations are derived from eastern ones and divergence times are congruent with the history of Mediterranean fruit tree domestication (Meyer et al., 2012). However, past records of carob tree from the palaeobotanical literature have never been the subject of a comprehensive review. In addition, a long-standing evolutionary history in the Mediterranean that precedes the origin of the agriculture could also explain the presence of $C$. siliqua in several types of thermophilous vegetation across the Mediterranean (Baumel et al., 2018). Therefore, alternative scenarios should be tested when addressing the origin of the carob tree in the Mediterranean.

Here we present the first phylogeographic study of the carob tree across its distribution range in the Mediterranean basin to test the ERH versus an alternative scenario, which also has supporting independent evidences. First, we applied phylogenetic methods to estimate divergence time between the two Ceratonia species and to determine whether current populations of $C$. siliqua could have originated from domestication of $C$. oreothauma. Second, we investigated plastid DNA polymorphisms to document carob maternally-inherited lineages. Third, nuclear microsatellite (SSR) markers were used to identify the main carob genetic pools across the Mediterranean and analyzed under a statistical phylogeographic frame using Approximate Bayesian computation (ABC, Knowles 2009). Finally, we 
assessed our phylogeographic inferences by conducting a comprehensive review of palaeobotanical information and reconstructing the potential historical range dynamics of $C$. siliqua using species distribution modelling (SDM).

\section{Material and Methods \\ Plant material}

Leaves of 1067 carob trees from 78 populations were sampled across the Mediterranean between 2015 and 2017. Localities were selected to cover the geographical and ecological ranges of $C$. siliqua as described in Baumel et al. (2018; Table S1.1). Although discriminating wild carob trees from abandoned orchards was not always possible, most efforts were done to collect leaves of individuals from natural habitats. On the field, each sampled population was identified as cultivated or uncultivated and the possibility of human-mediated admixture was considered throughout the analyses (see below, Table S1.1). Ceratonia oreothauma was sampled from Edinburgh herbarium and Oman botanical garden material. DNA extraction method is described in Appendix S2.

\section{Divergence time analyses}

Molecular dating analyses were based on available data from Genbank database for two nuclear sucrose synthase (SUSY) copies and the plastid maturase K (matK) region (see Appendix S2). Divergence times were estimated using a Bayesian relaxed-clock approach implemented in BEAST v. 1.8.3 (Drummond $\&$ Rambaut, 2007). The concatenated dataset was run using a GTR + G model, a Yule speciation process prior, and an uncorrelated lognormal molecular clock. A fossil attributed to Ceratonia emarginata Heer from Central East Europe and dated at mid to Late Oligocene (Palamarev 1989) was used to calibrate the Ceratonia stem node (lognormal prior distribution, mean in real space $=28.1 \pm 0.2 \mathrm{Ma}$ ). Three secondary calibrations from Lavin et al. (2005) were applied to deeper nodes of the tree using normal prior distributions: i) $54 \pm 3.4 \mathrm{Ma}$ assigned to the Umtiza stem node, ii) $58.6 \pm 0.25 \mathrm{Ma}$ applied to the papilionoid stem node and, iii) $59 \pm 0.2$ Ma set to the legume stem node.

Plastid DNA haplotype variation within C. siliqua

Four plastid markers (matK gene, $p s b \mathrm{D}$-trn $\mathrm{T}$ spacer, $r p l 32-t r n \mathrm{~L}$ spacer and $c c S A-n d h \mathrm{D}$ spacer) were sequenced for $424 C$. siliqua and ten $C$. oreothauma individuals. A haplotype network was constructed with the concatenated dataset using TCS (Clement et al., 2000). Nucleotide diversity $(\pi)$ and Tajima's D (D) were computed with DNAsp (Rozas et al., 2017).

\section{Phylogeography of the carob tree based on nuclear microsatellite markers}

The development of 18 new SSR markers for carob tree and a method for genotyping microsatellites by high-throughput sequencing are described in Viruel et al. (2018). This genotyping improvement allows verifying the presence of paralogous copies and scoring separately SSR and SNP variation. One microsatellite marker was removed due to the difficulty to filter alleles between two paralogue copies and therefore 17 markers were finally used in our study. Because carob varieties are usually propagated by grafting, some sampled genotypes were found to be clones in the dataset and they were excluded from the analysis. The final dataset included 1037 multilocus genotypes. Genetic diversity was summarized at the level of the main genetic groups obtained from STRUCTURE analyses (see below) and the allelic richness $\left(N_{\mathrm{A}}\right)$, Shanon index, observed $\left(H_{\mathrm{O}}\right)$ and unbiased expected heterozygocity $\left(H_{\mathrm{E}}\right)$, and private allele rate (number of alleles by locus unique to a single genetic group) were computed with GENEALEX software (Peakall \& Smouse 2012). A map showing $N_{\mathrm{A}}$ and $H_{\mathrm{E}}$ per population was elaborated to document the geographical patterns of genetic diversity.

STRUCTURE software (Pritchard et al., 2000) was used to investigate the genetic structure based on SSR data, in which one to ten genetic groups $(K=1-10)$ were tested allowing admixture at individual level, with correlated allele frequencies and without prior information on geographical origin. Ten replicates were performed, each run having a burn-in period of 200,000 simulations and a chain length of 2,000,000 simulations. STRUCTURE HARVESTER (Earl \& vonHoldt 2012) was used to obtain likelihood values across the multiple values of $\mathrm{K}$ as well as to apply the delta $\mathrm{K}$ criterion to select the optimal $\mathrm{K}$ (Table S3.1). However, acknowledging the discrepancies between methods in choosing the optimal $\mathrm{K}$ (Janes et al., 2017), all the results of STRUCTURE from $\mathrm{K}=1$ to $\mathrm{K}=10$ computed with CLUMPAK (Kopelman et al., 2015) are shown in Appendix S3. In addition, to estimate genetic structure with a 
model-free method, we performed a hierarchical classification analysis of pairwise population genetic differentiation. A Jost's D differentiation matrix was analyzed with the Ward method based on within group variance criteria (Murtagh \& Legendre 2014). The population pairwise Jost's D differentiation matrix was computed with the MMOD package (Winter 2012) using 58 populations that contain at least 10 genotypes.

\section{Inferences on phylogeography by $A B C$}

We aimed to test the ERH versus an alternative hypothesis by conducting coalescent simulations and comparing models using an $\mathrm{ABC}$ approach. Models were constructed with a reduced number of genetic groups ( $\mathrm{K}=4$ from STRUCTURE analyses) used as populations in coalescent simulations. We aimed to minimize the confusing effects of recent admixture by assigning each population to a group according to their probability of membership obtained in STRUCTURE. For this purpose, a reduced dataset was used containing 38 populations (542 genotypes) with membership values above the median of each group (see Appendix S1).

The two candidate models for ABC analyses are shown in Figure 1. According to the ERH, current populations of carob tree would descend from an eastern refugium, and western populations would be more recently derived than central populations. The alternative model is supported by the plastid haplotype network, the palaeobotanical data, the SDM results and the $\mathrm{K}=2$ clustering from STRUCTURE (see Results): it assumes a phylogeographic split between eastern and western populations associated to two main refugia that led to two main genetic groups. This model, hereafter TRH (two refugia hypothesis), is also well supported by several phylogeographic studies focusing on widespread Mediterranean plants (Nieto Feliner 2014).

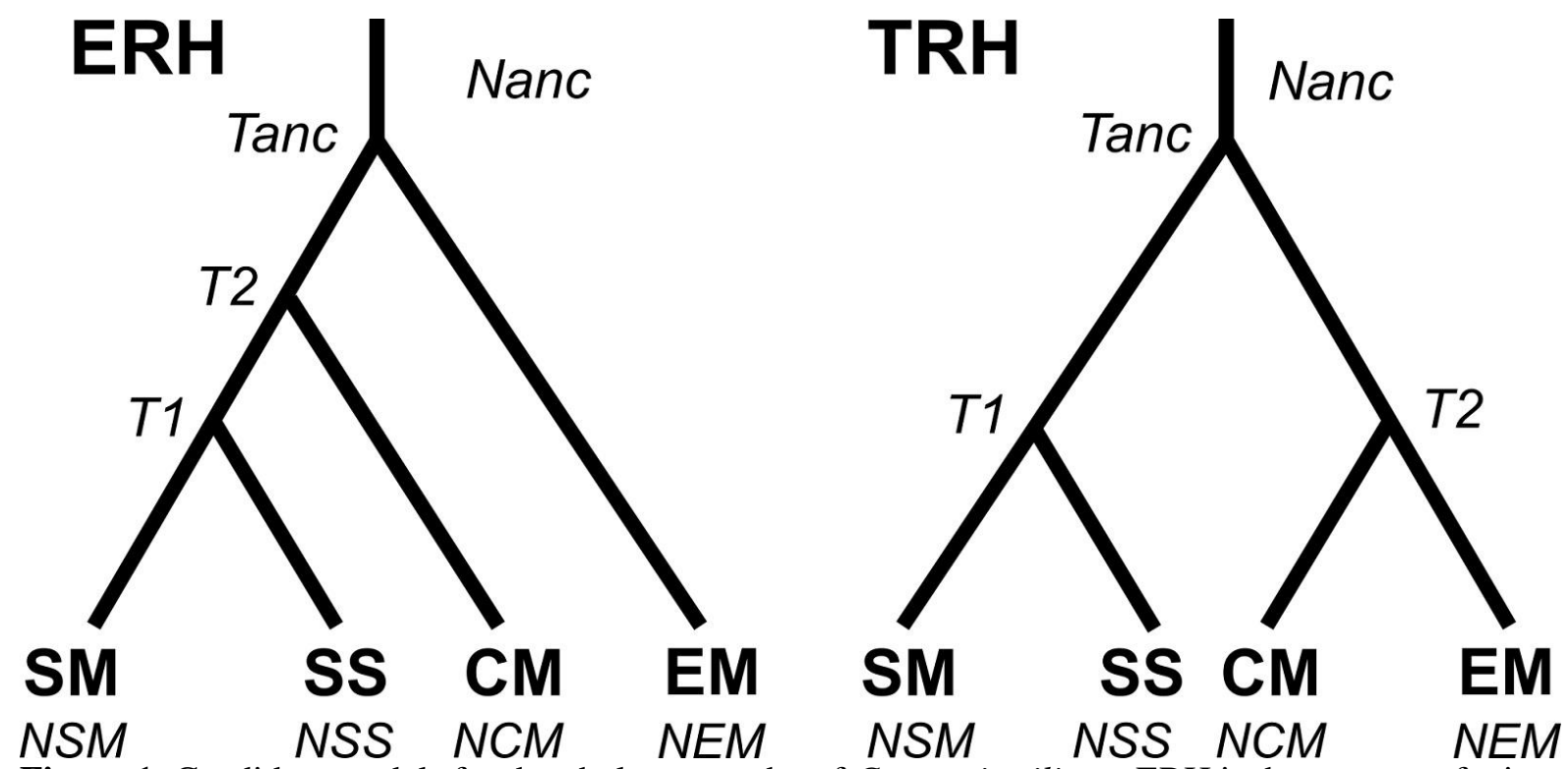

Figure 1: Candidate models for the phylogeography of Ceratonia siliqua. ERH is the eastern refugium hypothesis and TRH the two refugia hypothesis. SM, SS, CM and EM correspond to the Southern Morocco, South Spain, Central Mediterranean and Eastern Mediterranean genetic groups, respectively.

All coalescent simulations were done with FASTSIMCOAL 2.6 (Excoffier et al., 2011). For model selection $1 \times 10^{5}$ simulations were generated. The present and ancestral population effective sizes were drawn from uniform distributions. After the ancestral node (Tanc) the effective sizes remained constant. The details on coalescent simulations and prior distributions are given in Appendix S2. Allelic richness, expected heterozygosity, pairwise and overall $\mathrm{F}_{\mathrm{st}}$, as well as pairwise $\delta \mu^{2}$ were used as summary statistics for ABC and were computed using ARLSUMSTAT with ARLEQUIN (Excoffier \& Lischer 2010). Summary statistics used for ABC are given in Appendix 2. Model selection and parameter estimation was done according to Aoki et al. (2019). Confusion matrix, misclassification rate and model selection were performed in $\mathrm{R}$ with the Random forest approach implemented in the ABCRF package (Pudlo et 
al., 2015). One thousand trees were constructed, and the best model was selected by classification votes of random forest. Parameter inference was done for the selected model performing one million simulations, with the neural network method (R package ABC; Csilléry et al., 2012) and a logit transformation of parameter values, considering the closest 1000 simulations to the observed data (tolerance $=0.1 \%$ ). The 95\% highest posterior densities (HPD) were obtained with the HPDinterval function (R coda package, Plummer et al., 2006). The quality of parameters estimation was controlled in two different ways. First, posterior distributions of the parameters were compared to prior distributions based on density curves. We chose the mode of the posterior distribution after having controlled for the presence of a peak in posterior density curves. The posterior distributions of summary statistics were obtained from 1000 datasets simulated by using parameter values randomly sampled from parameters posterior distribution. The goodness-of-fit was checked by graphical inspection of the distance between observed data and posterior distribution of simulated data. To convert node ages in years we fixed a generation time for the carob tree, the details of our approach are detailed in Appendix S2.

\section{Environment Niche Modelling}

We included 650 occurrence points to model the distribution range of the carob tree using a consensus approach modelling procedure (Marmion et al., 2009) based on climatic variables at a 2.5 arc-min resolution from version 1.4 of the Worldclim database (Hijmans et al., 2005). We projected the species distribution under current, Mid-Holocene ( $\sim 6 \mathrm{ka})$, Last Glacial Maximum $(\sim 22 \mathrm{ka})$, and Last Interglacial $(\sim 130 \mathrm{ka})$ climatic conditions. More details about carob distribution modelling are given in Appendix 2 .

\section{Palaeobotanical information}

We performed a comprehensive survey of fossils in the literature resulting in a tentative summary of 55 occurrences of Ceratonia in the past (including macro-remains such as leaves, fruits, seeds, woods; and pollen grains; Table S2.5). A map was elaborated using GeoMapApp (Ryan et al., 2009).

\section{Results}

Divergence time analyses

Divergence time estimates (Figure S3.1) support a Late Miocene divergence between $C$. siliqua and its sister species $C$. oreothauma at $6.4 \mathrm{Ma}$ (95\%, HPD: 2.9-10.9). The divergence between the two main C. siliqua pDNA groups (see below) was estimated to occur during the Early Pleistocene (1.3 Ma, 95\%, HPD: 0.4-2.2).

\section{Geographical structure of plastid polymorphism}

Nine pDNA markers were tested for sequence variation and only four were polymorphic. The alignment of these four plastid markers has a length of $1472 \mathrm{bp}$. The presence of three substitutions and five indels identified six haplotypes in C. siliqua. Nucleotide diversity (0.00106), number of segregating sites (3) and Tajima's D $(3.34$, pval $<0.01)$ indicated low nucleotide variation and a lack of singletons. Three haplotypes were identified in $C$. oreothauma due to the existence of two indels. The haplotypes of $C$. siliqua and $C$. oreothauma differ by fifteen substitutions and four indels. 


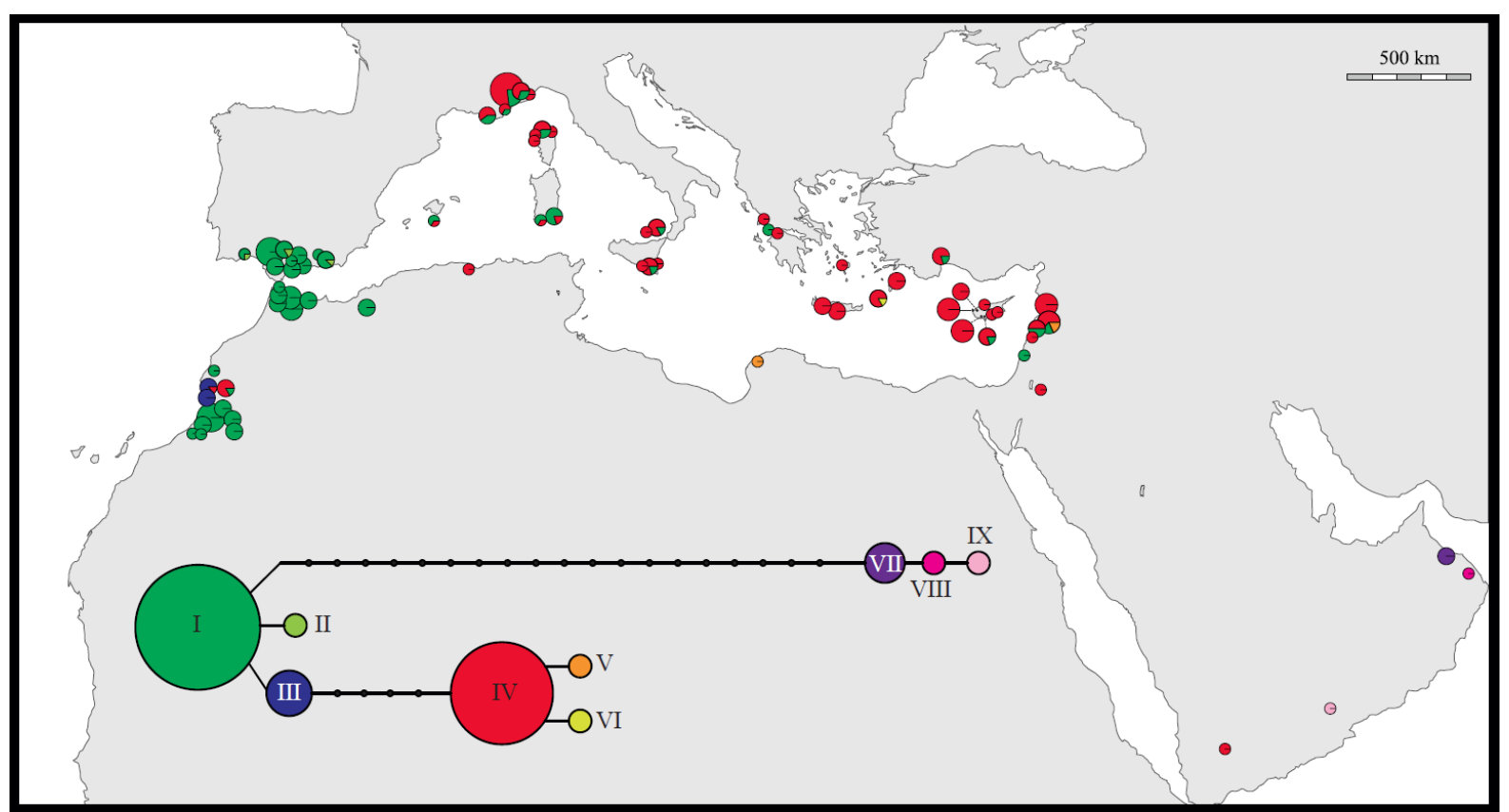

Figure 2: Geographic distribution of the plastid haplotypes identified in Ceratonia siliqua (I to VI) and C. oreothauma (VII to IX). In the haplotype network, the size of the circles is representative of sample size. Four markers were sequenced to obtain these haplotypes for a total of $1472 \mathrm{bp}$.

The network arranged the haplotypes of $C$. siliqua in two major groups mainly represented by haplotypes I and IV, respectively (Figure 2). The first group conformed by the haplotypes I, II and III is connected to $C$. oreothauma and its frequency is higher in the western part of the distribution range (Figure 2). Haplotypes IV, V and VI, forming the second group, differ by only one indel. This second group is more frequent in the East and is almost absent in the West except for Southern Morocco, in which the samples collected north of Agadir included the haplotypes III and IV. Most of the samples throughout the Mediterranean had either the haplotype I (219 samples) or IV (179 samples), whereas haplotype III was found in 11 samples all from South Morocco, haplotype II in three samples from Spain, and V and VI in three samples from the Eastern Mediterranean. In C. oreothauma, the most frequent haplotype VII was retrieved in 11 samples whereas haplotypes VIII and IX appeared in one and two samples, respectively.

\section{Structure of genetic diversity}

The 17 SSR markers revealed a total of 105 alleles with a mean of 6.2 alleles per locus. On average, 1033 genotypes were obtained per locus, and the overall mean observed heterozygosity was 0.47 , the expected heterozygosity 0.55 and the fixation index 0.14 .

The results of STRUCTURE from $\mathrm{K}=1$ to $\mathrm{K}=10$ are shown in Appendix 3, Figure S3.2. According to STRUCTURE HARVESTER results (Table S3.1), the best solutions are two or four genetic groups. No multimodality was observed for these solutions (Figure 3) and they are congruent with the Ward's clustering tree based on population pairwise Jost's D differentiations (Figure 3 and Figure S3.3) which clearly shows four main clusters that are grouped into two lineages. Although sub-optimal K solutions (e.g. $\mathrm{K}=3,5$ or 7 , Figure S3.2) present additional patterns, we focused here on two or four groups solutions that provide the best trade-off between STRUCTURE results and simplicity to test the ERH.

For $\mathrm{K}=2$, the first genetic group includes South Morocco and South Spain (in green, Figure 3) whereas the second group includes the genotypes from the remaining populations. The $\mathrm{K}=4$ clustering identified the following groups (Figure 3): SM, Southern Morocco; SS, Southern Spain; CM, Central Mediterranean including genotypes from Portugal, Algeria, France, Sardinia, Sicily and Balearics; EM, Eastern Mediterranean (i.e. Greece, Cyprus and Lebanon). 

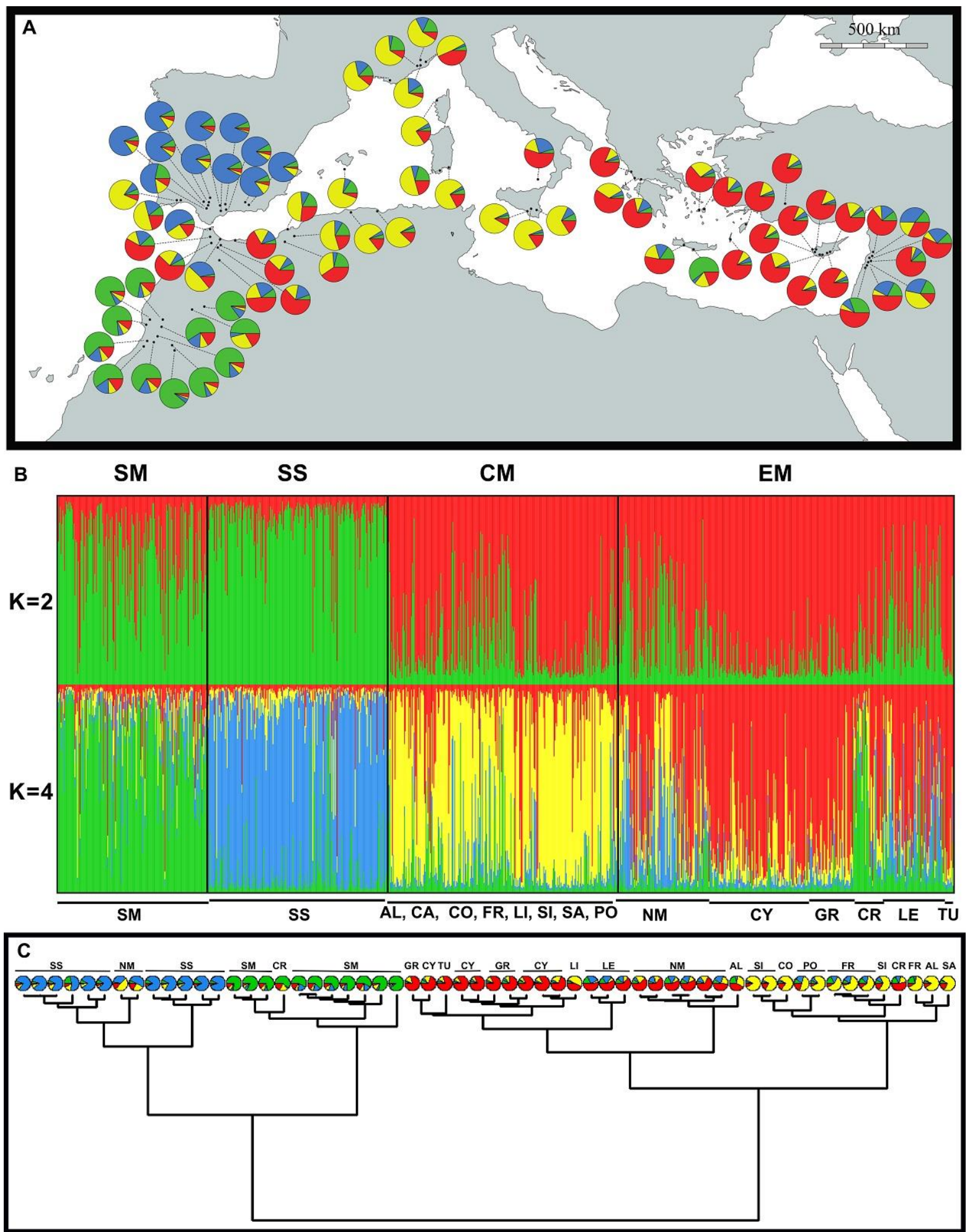

Figure 3: Genetic groups inferred for carob tree using 17 microsatellite markers. SM, Southern Morocco; SS Southern Spain; CM, Central Mediterranean; EM, Eastern Mediterranean. (A) Map of the membership frequencies of 1037 carob genotypes from 67 populations according to the $\mathrm{K}=4$ clustering solution of STRUCTURE. (B) Admixture proportions for $\mathrm{K}=2$ and $\mathrm{K}=4$ obtained from ten replicates in STRUCTURE (each 2000000 chain length after 200000 burn-in simulations, admixture model, no population prior) analyzed by CLUMPAK. Each sample is shown by a vertical bar partitioned according to its membership to one of the $\mathrm{K}$ groups. (C) Clustering tree obtained with Ward's method and pairwise Jost's D differentiation between populations having at least ten individuals (the tree with population names is shown in Figure S3.3). The pie charts corrrespond to admixture plots obtained with StruCTURE for $\mathrm{K}=4$ groups. AL, Algeria; CA, Cabrera; CO, Corsica; CR, Crete; CY, Cyprus; FR France; GR, Greece; LE, Lebanon; LI, Liguria; NM, North Morocco; PO, Portugal; SA, Sardinia; SI, Sicily. 
Admixture is observed in most populations and it is particularly strong in North Morocco, France, Crete and Lebanon (Figure 3). Six populations from North Morocco and one from Algeria were mostly assigned to a fourth group (EM) even though they show admixture with the other groups, whereas two population of North Morocco are assigned to South Spain (Figure 3). In Crete, one population is mostly assigned to the SM group (GRFAR) whereas the second is either assigned to the EM or CM group depending on the analysis (Figure 3). For ABC analysis, populations from North Morocco, Crete and some from Lebanon were excluded from the second analysis (see details of selection Table S1.1). The overall $F_{\text {st }}$ between the four groups is $6.7 \%$ when all populations are included and it is $10 \%$ when admixed populations are removed.

Table 1: Genetic diversity for the four main genetic groups of Ceratonia siliqua. $N$ is the number of trees screened, $M L G$ is the number of multilocus genotype obtained, $N a$ is the allelic richness, $\mathrm{Na}(>=5 \%)$ is the allelic richness restricted to allele having a minimum frequency of $5 \%, I$ is the Shannon index, $H o$ is the observed heterozygosity, $H_{\mathrm{E}}$ is the unbiased expected heterozygosity, $F$ is the fixation index and Priv is the private allelic rate.

\begin{tabular}{llllllllll}
\hline Genetic group & N & MLG & Na & $\mathbf{N a}(>=5 \%)$ & I & Ho & $\mathbf{H}_{\mathbf{E}}$ & $\mathbf{F}$ & Priv \\
\hline South Morocco (SM) & 176 & 167 & 5.5 & 3 & 1.08 & 0.51 & 0.58 & 0.11 & 0.47 \\
South Spain (SS) & 207 & 206 & 4.6 & 3.2 & 1.03 & 0.53 & 0.56 & 0.06 & 0.06 \\
Central Med. (CM) & 282 & 275 & 5.1 & 2.7 & 0.88 & 0.43 & 0.48 & 0.08 & 0.12 \\
East Med. (EM) & 402 & 392 & 5.2 & 3.1 & 0.98 & 0.46 & 0.53 & 0.12 & 0.18 \\
Total population & 1067 & 1037 & 6.2 & 3.8 & 1.05 & 0.47 & 0.55 & 0.14 & \\
\hline
\end{tabular}

Summary of genetic diversity within the four main genetic groups (Table 1) revealed small differences in allelic richness but higher $H_{\mathrm{E}}$ and Shannon values in groups SS and SM, with the lowest values in group CM. Number of private markers are more than twice higher in SM than in EM but low in SS and CM. The map of $N_{\mathrm{A}}$ and $H_{\mathrm{E}}$ per population revealed higher scores in SM and SS and few populations in the East with high diversity (Figure S3.4).

Phylogeographic inferences by $A B C$

The model selected by the random forest $A B C$ analyses is graphically summarized in Figure 4. Classification error rates of ERH and TRH models were 14 and $19 \%$, respectively, for an overall error rate of $16.5 \%$. The TRH model received 951 votes from the 1000 classification trees, which allowed rejecting the ERH model. ABC supports TRH with a posterior probability of 0.92 , in which two divergent lineages derived from the ancestral node subsequently diverged into the current four genetic groups (Figure 4). Parameters inferred for the most probable model are indicated in Table S3.2. The mode was used as a point estimate for all parameters after graphical inspection of posterior distributions (Figure S3.5). Comparisons of distribution of simulated summary statistics (1000 datasets) with values of the observed summary statistics showed a good congruence between simulated and observed statistics confirming the goodness of fit for the selected model (Figure S3.6). 


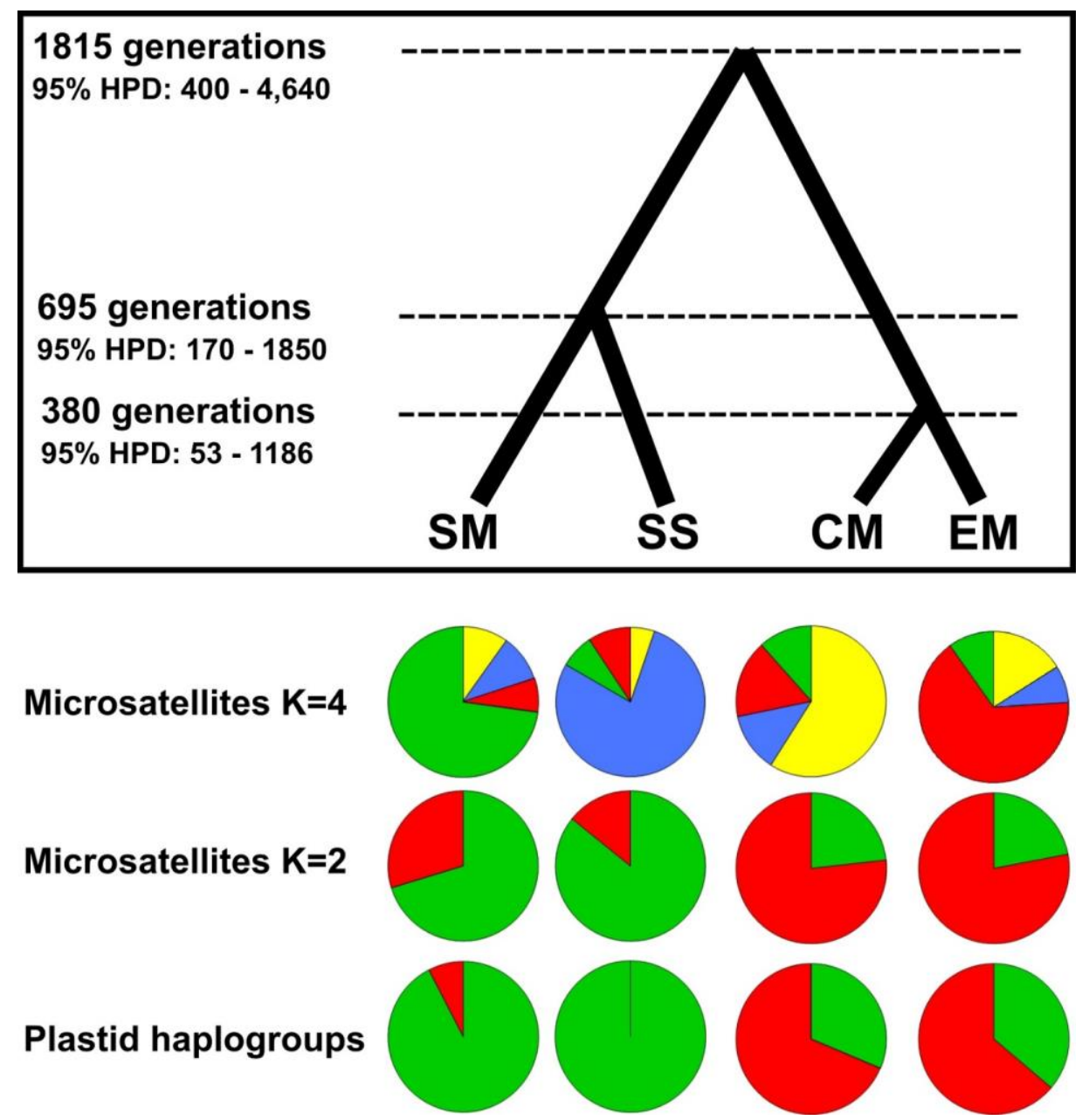

Figure 4: The best fitting model inferred by $\mathrm{ABC}$ and admixture proportions from microsatellites data (STRUCTURE models for $\mathrm{K}=2$ and $\mathrm{K}=4$, full data set of 1037 carob genotypes from 67 provenances) and plastid markers data. $\mathrm{SM}=$ Southern Morocco. $\mathrm{SS}=$ South Spain. $\mathrm{CM}=$ Central Mediterranean. $\mathrm{EM}=$ Eastern Mediterranean. Plastid haplogroups, in green haplotypes I, II and III, in red haplotypes IV, $\mathrm{V}$ and VI.

$\mathrm{ABC}$ analyses estimated 1815 generations to the ancestral node, 695 generations to the node between SM and SS and 380 generations to the node between CM and EM (Table S3.2 and Figure 4). Assuming a generation time of 64 years for carob tree (see Appendix S2), the ancestral divergence of the carob lineages would be dated to $116 \mathrm{ka}$ (95\% HPD 25 - $297 \mathrm{ka}$ ), the split between South Morocco and South Spain to $44 \mathrm{ka}$ (95\% HPD $10-118 \mathrm{ka}$ ) and the split between the central and eastern groups to $24 \mathrm{ka}$ (95\% HPD $3 \mathrm{ka}-76 \mathrm{ka}$ ). These nodes ages, despite their large 95\% HPD, have well peaked distribution modes (Figure S3.5) supporting that the main genetic groups of the carob tree diverged well before the onset of crop tree domestication in the Mediterranean.

Distribution hindcasting and past occurrences of the carob

Distribution modelling for past periods infers a potential contraction towards the south during the Last Glacial Maximum (LGM) at about $22 \mathrm{ka}$, with suitable environmental conditions persisting below $41^{\circ}$ of latitude. This result is consistent for three Global Circulation Models used here (Appendix 3, Figure S3.7) although only the results from the CCSM4 model are shown in Figure 5. The strongest change is inferred during the Last Interglacial (LIG) at about $130 \mathrm{ka}$ (Figure 5) with suitable conditions for the species restricted to the Atlantic coasts of Morocco, Spain and Portugal, which suggests extinction or very strong contraction elsewhere. 

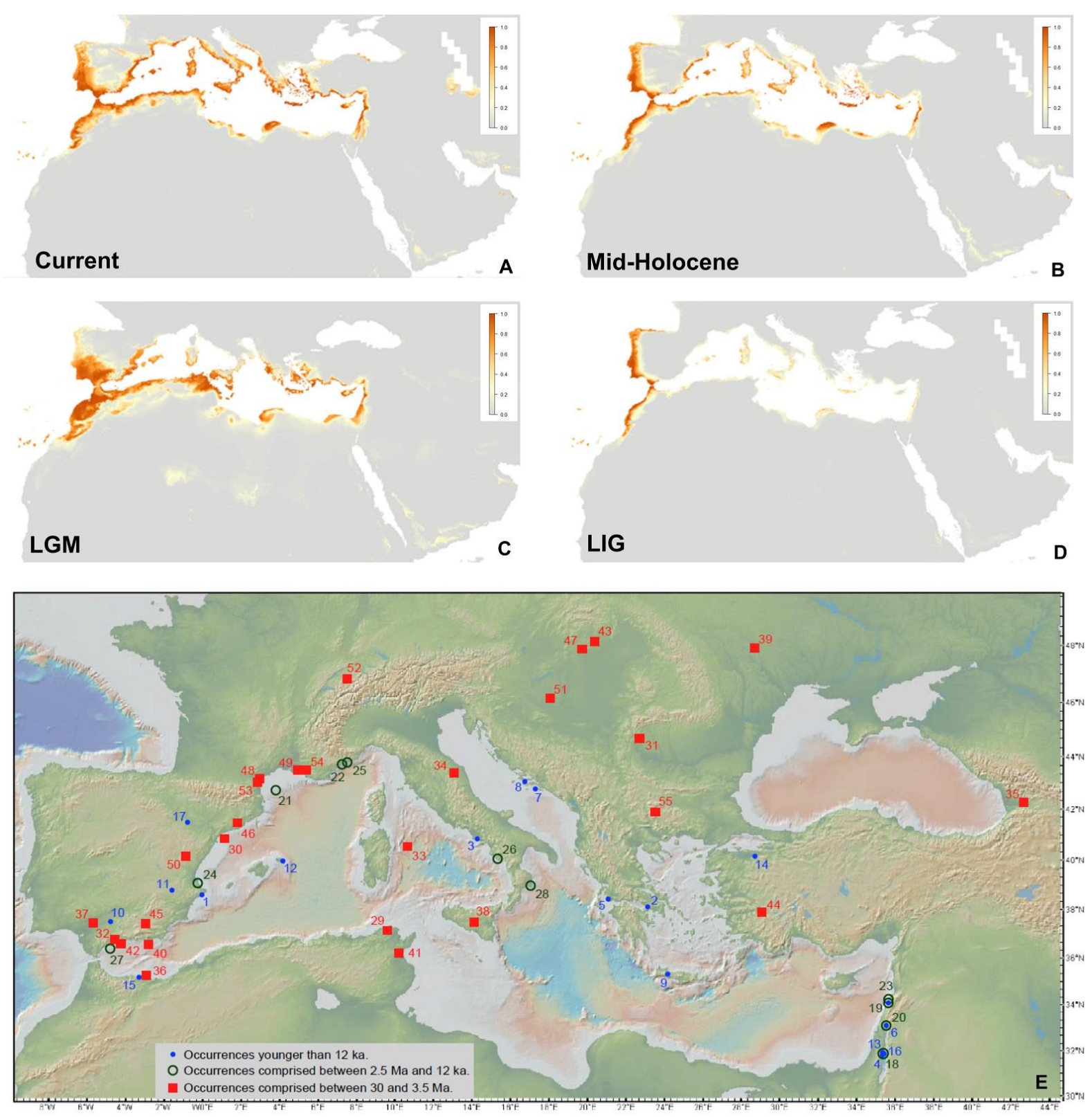

Figure 5: Species distribution modelling of the carob in four periods (A, Present; B, Mid-Holocene; C, Last Glacial Maximum (LGM); D, Last Inter-Glacial (LIG)), and E, Map of palaeobotanical data of Ceratonia from Oligocene to Middle Ages (macroremains and pollen grains). Numbers correspond to the input order of data in Table S2.5 from the youngest (No.1, Middle Ages) to the oldest data (No.55, Early Oligocene).

Forty-four references allowed compiling 55 past occurrences of Ceratonia mostly based on pollen records (Table S2.5). Mapped fossil records (Figure 5) indicate a mostly continuous presence of Ceratonia from Oligocene to Late Pliocene around the palaeo-Mediterranean Sea (including the former Paratethys) which progressively reduced from $20 \mathrm{Ma}$ up to its modern physiography reached at $c a .3 .6$ Ma. The Early Pleistocene occurrences are restricted to southwestern Europe (localities 25 - 28) but Middle and Late Pleistocene occurrences (18-24) are located in the East and the West. Although pollen grains and macro-remains records of Early Holocene were reported mainly from the Middle East, two western occurrences for this period (dated at ca. $11 \mathrm{ka}$, localities 17 and 15), indicate the probable presence of the carob tree before domestication in the Western Mediterranean. 


\section{Discussion}

Reconstructing the phylogeography of cultivated fruit trees is challenging due to their long generation time, the vegetative propagation conducted by farmers and the recurrent exchanges between cultivated and wild populations. All these aspects are found in the carob tree, but our multidisciplinary study has unveiled relevant evidences that allow a better understanding of its natural history and domestication. Divergence time analyses estimated an origin for Ceratonia near the Oligocene/Miocene boundary and a split between $C$. siliqua and $C$. oreothauma around the Late Miocene. The fossil pollen records found during the Miocene in the Mediterranean are morphologically similar to modern $C$. siliqua and differ from the pollen of its sister species, C. oreothauma, by the number of apertures and surface ornamentation (Figure S2.3). The geographic distribution of the Ceratonia fossil records prior to 3.5 Ma was linked to the tropical-subtropical wide northern margin of the paleo-Mediterranean Sea (Bessedik et al., 1984), corresponding to the pre-Mediterranean sclerophyllous vegetation (Axelrod, 1975; Jiménez-Moreno and Suc, 2007). In the Pleistocene, after the onset of the Mediterranean climate, it is noteworthy that a blatant thermophilous forest community with Ceratonia and Olea was identified by $1.4 \mathrm{Ma}$ pollen records at Camerota (S Italy) (Olea: 10\% and Ceratonia: 12\% of the pollen assemblage; Brenac, 1984). Fossil data and our phylogenetic results identified carob tree as a "preMediterranean" lineage (Herrera, 1992) and its ancestors probably were widely distributed around the Tethys Sea during the Paleogene (Palamarev, 1989) in tropical forests that were impoverished by the successive extinctions during the transition towards the Mediterranean climate (Suc, 1984; Mijarra et al., 2009; Suc et al., 2018). Fossil records of the carob dated during the Pleistocene were found both in the western and eastern Mediterranean, therefore not supporting the ERH.

The overall SSR allelic richness of the carob tree $\left(N_{\mathrm{A}}=6.2\right.$; and 3.8 when rare alleles are excluded $)$ is low compared to values published in recent studies of Mediterranean trees using microsatellites, such as Olea europaea L. ( $N_{\mathrm{A}}=16$, Diez et al., 2015), Prunus dulcis (Mill.) D.A. Webb ( $N_{\mathrm{A}}=17$, Delplancke et al., 2012), or Phoenix dactylifera L. ( $N_{\mathrm{A}}=13$, Zehdi-Azouzi et al., 2015); but higher than in the Tertiary relict Platanus orientalis L. $\left(N_{\mathrm{A}}=1.9\right.$, Rinaldi et al., 2019). La Malfa et al. (2014) reported a very similar $N_{\mathrm{A}}$ value of 3.1 for nine SSR markers screened in carob cultivars from Italy, Malta and Spain. Plastid allele richness is also very low with only six haplotypes and most of the range is represented by only two of them. The positive Tajima's D result obtained with plastid data is supporting a strong demographic decline in the past. These results contrast with the higher plastid diversity observed in other Mediterranean trees like Erica arborea L., Olea europaea or Myrtus communis L. (Désamoré et al., 2011; Besnard et al., 2017; Migliore et al., 2018); but are congruent with the low plastid variation observed in Laurus nobilis L. (Rodriguez-Sanchez et al., 2009) and even higher than in Celtis occidentalis L. and Nerium oleander L. (Mateu-Andres et al., 2015). Nuclear and plastid markers therefore indicate low levels of allelic richness for the carob tree which are consistent with a strong decline scenario. If an expansion followed this decline, it should have been too recent to allow for the recovery of plastid variation. As indicated above, this past decline of the carob tree in consistent with palaeobotanical data and SDM results.

Far from confirming the ERH, genetic data supports an alternative hypothesis for the carob tree history. First, the strong west-east plastid differentiation rejects an exclusive eastern origin (Figure 2). Second, clustering of microsatellite polymorphisms revealed that populations from Southern Morocco and Southern Spain form a distinct cluster and exhibit higher genetic diversity (Figure S3.4). Therefore, an extended presence of the carob tree in the Western Mediterranean is strongly supported by the simple description of genetic diversity structure. Finally, ABC analyses also rejected the ERH. A similar ERH was also proposed in the past for the olive tree but genetic data sampled throughout the Mediterranean support a different scenario (Breton et al., 2006; Besnard et al., 2017).

The most likely scenario for the phylogeography of the carob tree depicts two lineages (Figure 4), one being restricted to the westernmost part of its range. A subsequent divergence found within this western lineage is older than the split between the central and eastern genetic groups, supporting an older and larger persistence in the western margin of the range. Such an old western occurrence is also supported by the higher genetic diversity and originality (private markers) scored in the western lineage for both plastid and SSR markers. Calculating a specific timing for this scenario is highly dependent on the 
generation time, which remains difficult to be estimated for trees (e.g. Cavender-Bares et al., 2011; Tsuda et al., 2015). However, despite uncertainties on generation time and the large confidence intervals for divergence times, the origin of the four lineages recognized within $C$. siliqua (116 ka) substantially preceded its domestication, which may have started ca. 3 ka (Meyer et al., 2012), as well as the first tree crop domestication records ca. 6 ka (Zohary \& Hopf 2012). Phylogeography and palaeobotany thus support a native status of the carob tree throughout the Mediterranean.

Independently from molecular data, SDM results are also consistent with a range contraction towards a western refugium along the Atlantic coast during the LIG (Fig. 5). This unexpected pattern for a thermophilous tree could be due to an increased climatic continentality (i.e. colder winters and warmer as well as drier summers), which was more pronounced in the East during LIG times (Felis et al., 2004). This modelled response of the carob tree to the drastic reduction of its suitable range is consistent with the confidence interval for its likely ancestral node age coinciding with the Eemian period (130 - 115 $\mathrm{ka}$, LIG) and would explain the strong population decline estimated by molecular data. A similar range contraction during the LIG was recently inferred for the thermophilous shrub Lavatera maritima (VillaMachío et al., 2018).

The genetic diversity of the carob tree is also characterized by introgression events between the main four lineages. Carob trees from Northern Morocco, which belong to the Western plastid haplogroup, are mostly assigned to the EM group while having memberships for the SS and CM groups. This incongruence between nuclear and plastid markers, also observed in one population of Crete, could be explained by long-term effects of asymmetric introgressions during the expansion of cultivated carob trees, as proposed in the theoretical study of Currat et al. (2008). According to these authors, plastid markers are particularly prone to such process. In North Morocco, this incongruence strongly suggests that the invading genetic pool was largely introgressed by the resident wild carobs bearing the western haplotype, which was fixed in the admixed populations. Further studies will explore this hypothesis and whether such expansions and introgressions could have taken place in the Roman or Arab times in Northern Morocco. In Lebanon and France, a strong admixture was observed but in this case for both plastid and nuclear markers, which may suggest a more recent contact between the two main lineages.

\section{Conclusion}

Our multidisciplinary study based on phylogeography, palaeobotany and species distribution modelling clarified an enduring controversy on the origin of the carob, an important fruit tree for the Mediterranean cultures. We provide strong support for the existence of four lineages within $C$. siliqua that evolved before the major civilizations of the Fertile Crescent and the Mediterranean.

Our results are very supportive of the persistence of the carob tree in Moroccan and Iberian refugia but they do not discard the existence of smaller refugia in the Eastern Mediterranean. SDM predicts small suitable areas in this region during the LIG and both plastid and microsatellite patterns of variation indicate a strong east-west divergence. We thus propose a new hypothesis according to which current C. siliqua populations originated from two disjunct refugia after LIG.

The previously accepted eastern domestication hypothesis is also difficult to reconcile with our data because cultivated carobs are present within the four lineages discovered here. The role of Greek, Roman and Arab farmers in the history of the carob was certainly important for the dissemination of carob cultivation practices and cultivars, but our results support a local use and domestication of the carob tree from native populations throughout the Mediterranean.

\section{Acknowledgement:}

This study is part of the DYNAMIC project supported by French national agency of research (ANR14-CE02-0016) and benefited from equipment and services from the molecular biology facility (SCBM) at IMBE (Marseille, France) and from the genotyping and sequencing core facility (iGenSeq) at ICM (Hôpital Pitié Salpêtrière, Paris, France). J.V. benefited from a Postdoc Fellowship funded by DYNAMIC and a Marie Skłodowska-Curie Individual Fellowship (704464 - YAMNOMICS - MSCAIF-EF-ST). The simulations and ABC were done on the "High Performance Computing Cluster" OSU Institut Pythéas (Aix Marseille Univ, INSU-CNRS). The authors thank for providing information or their help to complete our sampling: Annette Patzelt (Oman Botanic Garden), Minas Papadopulos 
(Department of Forests of Republic of Cyprus), Zahra Djabeur (Oran University), Nabil Benghanem (Tizi-Ouzou University), Gianluigi Bacchetta (Cagliari University), Sonja Yakovlev (Paris-Sud University), Errol Vela (CIRAD), Severine Fauquette (ISEM), Omar Boudouma (ISTeP), Maria Panitsa (Patras University), and the services of Junta de Andalucia.

The data used in this study is available on Genbank and Dryad, see the supporting information at the end of this document.

\section{REFERENCES}

Aoki, K., Tamaki, I., Nakao, K., Ueno, S., Kamijo, T., Setoguchi, H., ... Tsumura, Y. (2019). Approximate Bayesian computation analysis of EST-associated microsatellites indicates that the broadleaved evergreen tree Castanopsis sieboldii survived the Last Glacial Maximum in multiple refugia in Japan. Heredity, 122, 326-340.

Axelrod, D. I. (1975). Evolution and biogeography of Madrean-Tethyan sclerophyll vegetation. Annals of the Missouri Botanical Garden, 62, 280-334.

Baumel, A., Mirleau, P., Viruel, J., Boudagher Kharrat, M., La Malfa, S., Ouahmane, L., ... Médail, F. (2018). Assessment of plant species diversity associated with the carob tree (Ceratonia siliqua, Fabaceae) at the Mediterranean scale. Plant Ecology and Evolution, 151, 185-193.

Besnard, G., Terral, J.-F., \& Cornille A. (2017). On the origins and domestication of the olive: a review and perspectives. Annals of Botany, 121, 385-403.

Bessedik, M., Guinet, P., \& Suc, J.-P. (1984). Données paléofloristiques en Méditerranée nord-occidentale depuis l'Aquitanien. Revue de Paléobiologie, special volume, 25-31.

Brenac, P. (1984). Végétation et climat de la Campanie du Sud (italie) au Pliocène final d'après l'analyse pollinique des dépôts de Camerota. Ecologia mediterranea, 10, 207-216.

Breton, C., Tersac, M., \& Bervillé, A. (2006). Genetic diversity and gene flow between the wild olive (oleaster, Olea europaea L.) and the olive: several Plio-Pleistocene refuge zones in the Mediterranean basin suggested by simple sequence repeats analysis. Journal of Biogeography, 33, 1916-1928.

Candolle, A. de (1883). Origine des plantes cultivées. Germer Baillière et Cie.

Cavender-Bares, J., Gonzalez-Rodriguez, A., Pahlich, A., Koehler, K., \& Deacon, N. (2011). Phylogeography and climatic niche evolution in live oaks (Quercus series Virentes) from the tropics to the temperate zone. Journal of Biogeography, 38, 962-981.

Clement, M., Posada, D., \& Crandall, K. (2000). TCS: a computer program to estimate gene genealogies. Molecular Ecology 9, 1657-1660.

Csilléry, K., François, O., \& Blum, M. G. (2012). abc: an R package for approximate Bayesian computation (ABC). Methods in Ecology and Evolution, 3, 475-479.

Currat, M., Ruedi, M., Petit, R. J., \& Excoffier, L. (2008). The hidden side of invasions: massive introgression by local genes. Evolution, 62, 1908-1920.

Delplancke, M., Alvarez, N., Espíndola, A., Joly, H., Benoit, L., Brouck, E., \& Arrigo, N. (2012). Gene flow among wild and domesticated almond species: insights from chloroplast and nuclear markers. Evolutionary Applications, 5, 317-329.

Désamoré, A., Laenen, B., Devos, N., Popp, M., González- Mancebo, J. M., Carine, M. A., \& Vanderpoorten, A. (2011). Out of Africa: north- westwards Pleistocene expansions of the heather Erica arborea. Journal of Biogeography, 38, 164-176.

Diez, C. M., Trujillo, I., Martinez- Urdiroz, N., Barranco, D., Rallo, L., Marfil, P., \& Gaut, B. S. (2015). Olive domestication and diversification in the Mediterranean Basin. New Phytologist, 206, 436-447.

Drummond, A.J., \& Rambaut, A. (2007). BEAST: Bayesian evolutionary analysis by sampling trees. BMC Evolutionary Biology, 7, 214.

Earl, D. A., \& vonHoldt B.M. (2012). STRUCTURE HARVESTER: a website and program for visualizing STRUCTURE output and implementing the Evanno method. Conservation Genetics Resources, 4, 359-361.

Excoffier, L., \& Lischer, H. E. (2010). Arlequin suite ver 3.5: a new series of programs to perform population genetics analyses under Linux and Windows. Molecular Ecology Resources, 10, 564-567

Excoffier, L., \& Foll, M. (2011). Fastsimcoal: a continuous-time coalescent simulator of genomic diversity under arbitrarily complex evolutionary scenarios. Bioinformatics, 27, 1332-1334

Felis, T., Lohmann, G., Kuhnert, H., Lorenz, S. J., Scholz, D., Pätzold, J., ... Al-Moghrabi, S. M. (2004). Increased seasonality in Middle East temperatures during the last interglacial period. Nature, 429, 164-168.

Gavin D.G., Fitzpatrick M.C., Gugger P.F., Heath K.D., Rodríguez-Sánchez F., Dobrowski S.Z., ... Williams J.W. (2014). Climate refugia: joint inference from fossil records, species distribution models and phylogeography. New Phytologist, 204, 37-54.

Herrera, C. M. (1992). Historical effects and sorting processes as explanations for contemporary ecological patterns: character syndromes in Mediterranean woody plants. The American Naturalist, 140, 421-446. 
Hijmans, R.J., S.E. Cameron, J.L. Parra, P.G. Jones \& Jarvis A. (2005). Very high resolution interpolated climate surfaces for global land areas. International Journal of Climatology, 25,1965-1978.

Hillcoat D., Lewis G., \& Verdcourt, B. (1980). A New Species of Ceratonia (Leguminosae-Caesalpinioideae) from Arabia and the Somali Republic. Kew Bulletin, 35, 261.

Hu F.S., Hampe A., \& Petit R.J. (2009). Paleoecology meets genetics: deciphering past vegetational dynamics. Frontiers in Ecology and the Environment, 7, 371-379.

Janes, J. K., Miller, J. M., Dupuis, J. R., Malenfant, R. M., Gorrell, J. C., Cullingham, C. I., \& Andrew, R. L. (2017). The $\mathrm{K}=2$ conundrum. Molecular Ecology, 26, 3594-3602.

Jiménez-Moreno, G., \& Suc, J.-P. (2007). Middle Miocene latitudinal climatic gradient in Western Europe: evidence from pollen records. Palaeogeography, Palaeoclimatology, Palaeoecology, 253, 224-241.

Kopelman, N. M., Mayzel, J., Jakobsson, M., Rosenberg, N. A., \& Mayrose, I. (2015). Clumpak: a program for identifying clustering modes and packaging population structure inferences across K. Molecular Ecology Resources, 15, 1179-1191

Knowles, L. L. (2009). Statistical phylogeography. Annual Review of Ecology, Evolution, and Systematics, 40, 593-612.

La Malfa, S., Currò, S., Douglas, A. B., Brugaletta, M., Caruso, M., \& Gentile, A. (2014). Genetic diversity revealed by EST-SSR markers in carob tree (Ceratonia siliqua L.). Biochemical Systematics and Ecology, 55, 205-211.

Lavin, M., Herendeen, P. S., \& Wojciechowski, M. F. (2005). Evolutionary rates analysis of Leguminosae implicates a rapid diversification of lineages during the tertiary. Systematic Biology, 54, 575-594.

Marmion, M., Parviainen, M., Luoto, M., Heikkinen, R. K., \& Thuiller, W. (2009). Evaluation of consensus methods in predictive species distribution modelling. Diversity and Distributions, 15, 59-69.

Mateu-Andrés, I., Ciurana, M. J., Aguilella, A., Boisset, F., Guara, M., Laguna, E., ... Pedrola-Monfort, J. (2015). Plastid DNA homogeneity in Celtis australis L. (Cannabaceae) and Nerium oleander L.(Apocynaceae) throughout the Mediterranean Basin. International Journal of Plant Sciences, 176, 421-432.

Meyer R.S., Duval A.E., \& Jensen H.R. (2012). Patterns and processes in crop domestication: an historical review and quantitative analysis of 203 global food crops. New Phytologist, 196, 29-48.

Migliore J., Baumel A., Leriche A., Juin M., \& Médail F. (2018). Surviving glaciations in the Mediterranean region: an alternative to the long-term refugia hypothesis. Botanical Journal of the Linnean Society, 187, 537549.

Mijarra, J. M. P., Barrón, E., Manzaneque, F. G., \& Morla, C. (2009). Floristic changes in the Iberian Peninsula and Balearic Islands (southwest Europe) during the Cenozoic. Journal of Biogeography, 36, 2025-2043.

Murtagh, F., \& Legendre, P. (2014). Ward's hierarchical agglomerative clustering method: which algorithms implement Ward's criterion? Journal of classification, 31, 274-295

Nieto-Feliner, G. (2014). Patterns and processes in plant phylogeography in the Mediterranean Basin. A review. Perspectives in Plant Ecology, Evolution and Systematics, 16, 265-278.

Palamarev, E. (1989). Paleobotanical evidences of the Tertiary history and origin of the Mediterranean sclerophyll dendroflora. Plant Systematics and Evolution, 162, 93-107.

Peakall, R., \& Smouse, P. E. (2012). GenAlEx 6.5: genetic analysis in Excel. Population genetic software for teaching and research an update. Bioinformatics 28, 2537e2539.

Plummer, M., Best, N., Cowles, K., \& Vines, K. (2006). CODA: convergence diagnosis and output analysis for MCMC. R news, 6, 7-11

Pudlo, P., Marin, J. M., Estoup, A., Cornuet, J. M., Gautier, M., \& Robert, C. P. (2015). Reliable ABC model choice via random forests. Bioinformatics, 32, 859-866.

Pritchard, J. K., Stephens, M., \& Donnelly, P. (2000). Inference of population structure using multilocus genotype data. Genetics, 155, 945-959.

Quézel, P. \& Médail, F. (2003). Écologie et biogéographie des forêts du bassin méditerranéen. Elsevier, Paris, France.

Ramón-Laca, L. \& Mabberley, D.J. (2004). The ecological status of the carob-tree (Ceratonia siliqua, Leguminosae) in the Mediterranean. Botanical Journal of the Linnean Society, 144, 431-436.

Rinaldi, R., Cafasso, D., Strumia, S., Cristaudo, A., Sebastiani, F., \& Fineschi, S. (2019). The influence of a relict distribution on genetic structure and variation in the Mediterranean tree, Platanus orientalis L. AoB PLANTS, 11, plz002.

Rodríguez-Sánchez, F., Guzmán, B., Valido, A., Vargas, P., \& Arroyo, J. (2009). Late Neogene history of the laurel tree (Laurus L., Lauraceae) based on phylogeographical analyses of Mediterranean and Macaronesian populations. Journal of Biogeography, 36, 1270-1281.

Rozas J., Ferrer-Mata A., Sánchez-Delbarrio J.C., Guirao-Rico S., Librado P., Ramos-Onsins S.E., \& SánchezGracia A. (2017). DnaSP 6: DNA Sequence Polymorphism Analysis of Large Data Sets. Molecular Biology and Evolution, 34, 3299-3302. 
Ryan, W. B. F., Carbotte, S. M., Coplan, J. O., O'Hara, S., Melkonian, A., Arko, R., Weissel, R. A., Ferrini, V., Goodwillie, A., Nitsche, F., Bonczkowski, J., \& Zemsky, R. (2009). Global Multi-Resolution Topography synthesis. Geochemistry Geophysics Geosystems, 10, Q03014.

Servera-Vives G., Riera S., Picornell-Gelabert L., Moffa-Sánchez P., Llergo Y., Garcia A., ... Trías M.C. (2018). The onset of islandscapes in the Balearic Islands: A study-case of Addaia (northern Minorca, Spain). Palaeogeography, Palaeoclimatology, Palaeoecology, 498, 9-23.

Suc, J. P. (1984). Origin and evolution of the Mediterranean vegetation and climate in Europe. Nature, $307,429$. Suc, J.-P., Popescu, S.-M., Fauquette, S., Bessedik, M., Jiménez-Moreno, G., Bachiri Taoufiq, N., Zheng, Z., \& Médail, F. (2018) Reconstruction of Mediterranean flora, vegetation and climate for the last 23 million years based on an extensive pollen dataset. Ecologia mediterranea, 44, 53-85.

Tsuda, Y., Nakao, K., Ide, Y., \& Tsumura, Y. (2015). The population demography of Betula maximowicziana, a cool-temperate tree species in Japan, in relation to the last glacial period: its admixture- like genetic structure is the result of simple population splitting not admixing. Molecular Ecology, 24, 1403-1418.

Villa-Machío, I., Fernández de Castro, A. G., Fuertes-Aguilar, J., \& Nieto Feliner, G. (2018). Out of North Africa by different routes: phylogeography and species distribution model of the western Mediterranean Lavatera maritima (Malvaceae). Botanical Journal of the Linnean Society 187, 441-445.

Viruel J., Haguenauer A., Juin M., Mirleau F., Bouteiller D., BoudagherKharrat M., ... Baumel A. (2018). Advances in genotyping microsatellite markers through sequencing and consequences of scoring methods for Ceratonia siliqua (Leguminosae). Applications in Plant Sciences, 6:e1201.

Winter, D. J. (2012). MMOD: an R library for the calculation of population differentiation statistics. Molecular Ecology Resources, 12, 1158-1160.

Zapata L., López-Sáez J.A., Ruiz-Alonso M., Linstädter J., Pérez-Jordà G., Morales J., ... Peña-Chocarro L. (2013). Holocene environmental change and human impact in NE Morocco: Palaeobotanical evidence from Ifri Oudadane. The Holocene, 23, 1286-1296.

Zehdi-Azouzi, S., Cherif, E., Moussouni, S., Gros-Balthazard, M., Abbas Naqvi, S., Ludeña, B., ... Si-Dehbi, F. (2015). Genetic structure of the date palm (Phoenix dactylifera) in the Old World reveals a strong differentiation between eastern and western populations. Annals of Botany, 116, 101-112.

Zohary D. (2002). Domestication of the carob (Ceratonia siliqua L.). Israel Journal of Plant Sciences, 50, 14115.

Zohary D. \& Hopf M. (2012). Domestication of plants in the Old World: the origin and spread of cultivated plants in West Asia, Europe and the Nile Valley. Oxford University Press.

\section{BIOSKETCH}

Juan Viruel is working on conservation genetics of plants and all the authors are interested on several aspect of plant ecology and evolution including crops and their wild relatives. This work is part of an international project on carob biogeography, microbiology and ecology (https://dynamic.cirad.fr).

Author contributions: H.S. and A.B. planned this project. J.V., J.P.S., N.L.G., G.N.F., S.P., F.M. and A.B. conceived the ideas; A.B., F.M., G.N.F., M.B.K., L.O., S.L.M., K.D., H.S. and J.V. conducted the fieldwork and collected the data with additional material from collaborators; F.L.M., M.S., and J.V. conducted the laboratory work; A.B., N.L.G., J.P.S., S.P. and J.V. analyzed the data; A.B. and J.V. led the writing with assistance from G.N.F., S.P., F.M. and J.P.S.. All authors gave final approval for publication.

\section{DATA ACCESSIBILITY}

- Sampling information, extended laboratory and statistical methods, as well as extended results are available in supporting information.

- GenBank accessions of plastid haplotypes and SUSY sequences acquired for Ceratonia are available in supporting information.

- In DRYAD repository (https://doi.org/10.5061/dryad.k7m020r) are available:

- Sequences alignments (fasta files) used for phylogeography and divergence time analysis.

- Microsatellites genotypes.

- STRUCTURE results

- Occurrence points used for SDM 


\section{SUPPORTING INFORMATION}

APPENDIX S1 Ceratonia sampling information

APPENDIX S2 Extended material \& methods.

APPENDIX S3 Extended results 


\section{APPENDIX S1 Ceratonia sampling information}

TABLE S1: Locality information of the populations of carob tree included in this study. 'Pop_ID' refers to the population codes used in the tables available in the Dryad Digital Repository (https://doi.org/10.5061/dryad.k7m020r). 'N_ $\mu$ sat' is the number of samples genotyped by microsatellite marker, and 'N_pDNA' is the number of samples for which the four plastid markers were sequenced (Table S2.1). 'Admix' values show the mean membership of each population to one of the four clusters assigned by Structure results (SM, SS, CM and EM). For ABC analyses, only the populations with membership values higher than the median of the cluster were used. SM= South Morocco, SS = South Spain, CM = Central Mediterranean, EM= Eastern Mediterranean.

\begin{tabular}{|c|c|c|c|c|c|c|c|c|c|c|c|c|}
\hline Pop_ID & Country & Location & N_usat & N_pDNA & Longitude & Latitude & Status & admix_SM & admix_SS & admix_CM & admix_EM & $\mathbf{A B C}$ \\
\hline ALGAB & Algeria & Sidi Bel Abbès & 9 & 0 & -0.543853 & 35.120683 & uncultivated & 0.1673 & 0.0866375 & 0.5430125 & 0.2030625 & \\
\hline ALGGOU & Algeria & $\begin{array}{l}\text { Gouraya mountain near } \\
\text { Bejaia }\end{array}$ & 20 & 2 & 5.079751 & 36.764385 & uncultivated & 0.05552 & 0.02905 & 0.79511 & 0.12032 & $\mathrm{CM}$ \\
\hline ALGMESS & Algeria & Messerghine & 9 & 0 & -0.863352 & 35.670302 & uncultivated & 0.171825 & 0.0941125 & 0.4668875 & 0.2671875 & \\
\hline ALGTAB & Algeria & Tabouinèt, Blida & 8 & 0 & 3.04335 & 36.5191833 & uncultivated & 0.045825 & 0.04455 & 0.7670375 & 0.1425875 & $\mathrm{CM}$ \\
\hline ALGTLEM & Algeria & Tlemcem, El Ourit & 13 & 5 & -1.32 & 34.89 & uncultivated & 0.211938462 & 0.051015385 & 0.332092308 & 0.404946154 & \\
\hline CHAKA & Cyprus & Akamas, Neo Chorio & 24 & 11 & 32.3352 & 35.02555 & uncultivated & 0.04663913 & 0.059313043 & 0.080208696 & 0.813834783 & EM \\
\hline CHANO & Cyprus & Anogyra & 32 & 12 & 32.74097 & 34.74728 & cultivated & 0.032281818 & 0.048540909 & 0.2143 & 0.704877273 & EM \\
\hline CHAVA & Cyprus & Avakas, Paphos & 19 & 3 & 32.337821 & 34.919507 & uncultivated & 0.069917647 & 0.023011765 & 0.084747059 & 0.822323529 & EM \\
\hline CHKOF & Cyprus & Kofinou & 11 & 5 & 33.396846 & 34.853211 & cultivated & 0.082863636 & 0.0489 & 0.157254545 & 0.710972727 & EM \\
\hline CHLYS & Cyprus & Lysos & 11 & 5 & 32.53441 & 34.9995 & uncultivated & 0.023 & 0.037690909 & 0.127672727 & 0.811627273 & EM \\
\hline CHSAN & Cyprus & Sanida & 10 & 2 & 33.22641 & 34.79309 & uncultivated & 0.03236 & 0.04392 & 0.08298 & 0.84074 & EM \\
\hline CHSOT & Cyprus & Sotira & 9 & 5 & 32.85653 & 34.714946 & cultivated & 0.025433333 & 0.030744444 & 0.099744444 & 0.844066667 & EM \\
\hline CHSTE & Cyprus & Steni & 7 & 1 & 32.47223 & 35.0037 & cultivated & 0.032842857 & 0.039028571 & 0.390728571 & 0.5374 & \\
\hline ESACE & Spain & El Acebuchal & 13 & 5 & -3.92639 & 36.81622 & cultivated & 0.070961538 & 0.780769231 & 0.108476923 & 0.0398 & \\
\hline ESALH & Spain & Alhaurin & 20 & 7 & -4.72978 & 36.61124 & uncultivated & 0.084035 & 0.8162 & 0.060505 & 0.039275 & SS \\
\hline ESBEN & Spain & Benaocaz & 16 & 5 & -5.43861 & 36.69741 & uncultivated & 0.08190625 & 0.8040375 & 0.05410625 & 0.05994375 & SS \\
\hline ESCAB & Spain & Cabrera Island & 7 & 3 & 2.951 & 39.141 & uncultivated & 0.1589 & 0.066657143 & 0.717728571 & 0.056714286 & SS \\
\hline ESELB & Spain & El bosque & 20 & 7 & -5.47019 & 36.701 & cultivated & 0.069015 & 0.77751 & 0.10024 & 0.053245 & \\
\hline ESGRA & Spain & Grazalema & 20 & 6 & -5.41916 & 36.75605 & uncultivated & 0.0532 & 0.831765 & 0.08256 & 0.032475 & SS \\
\hline ESNER & Spain & Nerja & 11 & 8 & -3.85342 & 36.76867 & uncultivated & 0.067281818 & 0.823409091 & 0.086881818 & 0.022427273 & SS \\
\hline ESOJE & Spain & Ojen & 20 & 7 & -4.88065 & 36.57748 & uncultivated & 0.080125 & 0.84329 & 0.032065 & 0.04452 & SS \\
\hline ESPIC & Spain & El Picacho, Sierra del Aljibe & 29 & 5 & -5.649944 & 36.521861 & uncultivated & 0.215424138 & 0.561465517 & 0.134293103 & 0.088817241 & \\
\hline ESPIZ & Spain & Pizarra & 21 & 7 & -4.6997 & 36.76009 & cultivated & 0.070755 & 0.872135 & 0.02113 & 0.035985 & SS \\
\hline ESUBR & Spain & Ubrique & 20 & 7 & -5.44537 & 36.66859 & uncultivated & 0.054305 & 0.79426 & 0.08639 & 0.065035 & \\
\hline ESYUN & Spain & Yunquera & 17 & 3 & -4.90068 & 36.73414 & cultivated & 0.100076471 & 0.815570588 & 0.0235 & 0.060852941 & SS \\
\hline FRCOR & France & $\begin{array}{l}\text { Isolated trees in villages } \\
\text { between Piana and Calvi, } \\
\text { Corsica }\end{array}$ & 11 & 12 & 8.684197 & 42.463769 & cultivated & 0.04242 & 0.04674 & 0.75508 & 0.15576 & $\mathrm{CM}$ \\
\hline
\end{tabular}




\begin{tabular}{|c|c|c|c|c|c|c|c|c|c|c|c|c|}
\hline FREST & France & $\begin{array}{l}\text { Isolated trees, along the } \\
\text { road, Esterel }\end{array}$ & 0 & 3 & 6.892866 & 43.430742 & cultivated & NA & NA & NA & NA & \\
\hline FREZE & France & Grande Corniche, Eze & 20 & 11 & 7.38755 & 43.73848 & uncultivated & 0.09162 & 0.16468 & 0.69239 & 0.051315 & $\mathrm{CM}$ \\
\hline FRTLN & France & Mont Faron, Toulon & 20 & 10 & 5.92595 & 43.1462 & uncultivated & 0.12842 & 0.153855 & 0.60873 & 0.10899 & \\
\hline FRTOUET & France & Touët de l'escarène & 12 & 10 & 7.37336 & 43.85576 & uncultivated & 0.183016667 & 0.142675 & 0.587333333 & 0.086983333 & \\
\hline FRVIL & France & Villefrance sur mer & 21 & 15 & 7.32025 & 43.71703 & uncultivated & 0.220719048 & 0.043366667 & 0.647652381 & 0.088252381 & \\
\hline GRAST & Greece & Askatos & 6 & 1 & 21.070428 & 38.52721 & uncultivated & 0.065533333 & 0.121633333 & 0.0957 & 0.717116667 & $\mathrm{EM}$ \\
\hline GRFAR & Greece & Agio Farago, Crete & 20 & 6 & 24.779095 & 34.928205 & uncultivated & 0.605275 & 0.03705 & 0.166035 & 0.191635 & \\
\hline GRKAR & Greece & Karpatos & 6 & 6 & 27.1351111 & 35.6310806 & uncultivated & 0.034833333 & 0.054366667 & 0.09155 & 0.819266667 & EM \\
\hline GRKOU & Greece & $\begin{array}{l}\text { Koumoulia mountain, } \\
\text { Rhode island }\end{array}$ & 15 & 6 & 28.12085 & 36.350304 & uncultivated & 0.0277 & 0.038323077 & 0.1412 & 0.792769231 & EM \\
\hline GRLEU & Greece & Leucada island & 7 & 2 & 20.694513 & 38.674513 & uncultivated & 0.034728571 & 0.0417 & 0.108142857 & 0.815428571 & EM \\
\hline GRLOU & Greece & Loutro, Crete & 19 & 5 & 24.076279 & 35.198983 & uncultivated & 0.153742105 & 0.140257895 & 0.176615789 & 0.529352632 & \\
\hline GRNAX & Greece & Naxos island & 10 & 0 & 25.441915 & 36.94804 & uncultivated & 0.0702375 & 0.0694125 & 0.1041875 & 0.756175 & EM \\
\hline GRPAR & Greece & Paros island & 5 & 1 & 25.15753 & 37.018631 & uncultivated & 0.05315 & 0.044025 & 0.2652 & 0.637625 & \\
\hline GRXIR & Greece & Xiromero & 6 & 2 & 20.898655 & 38.714246 & uncultivated & 0.034188889 & 0.050311111 & 0.322877778 & 0.592622222 & \\
\hline ITAIRO & Italy & $\begin{array}{l}\text { La Roya valley, between } \\
\text { Trucco and Airole }\end{array}$ & 12 & 3 & 7.576777 & 43.858197 & uncultivated & 0.054016667 & 0.02525 & 0.486366667 & 0.434358333 & \\
\hline ITMONU & Italy & $\begin{array}{l}\text { Monumental carob trees } \\
\text { between Raguza and Noto, } \\
\text { Sicily }\end{array}$ & 11 & 3 & 14.88955556 & 36.88525 & cultivated & 0.079054545 & 0.098409091 & 0.662763636 & 0.159772727 & $\mathrm{CM}$ \\
\hline ITPAN & Italy & Panarea island, Sicily & 5 & 3 & 15.059 & 38.638 & uncultivated & 0.04514 & 0.25036 & 0.154 & 0.55048 & \\
\hline ITPIN & Italy & Pine Forest, Raguza, Sicily & 19 & 3 & 14.47618 & 36.87884 & cultivated & 0.040478947 & 0.027526316 & 0.848410526 & 0.083584211 & $\mathrm{CM}$ \\
\hline ITROOT & Italy & $\begin{array}{l}\text { Rootstock, Patrizio farm, } \\
\text { Raguza, Sicily }\end{array}$ & 35 & 12 & 14.610246 & 36.878135 & uncultivated & 0.026829412 & 0.03305 & 0.782241176 & 0.157873529 & $\mathrm{CM}$ \\
\hline ITSARR & Italy & Scillaras- Sarroca, Sardena & 5 & 3 & 8.95 & 39.128 & cultivated & 0.206466667 & 0.0824 & 0.505433333 & 0.205733333 & \\
\hline ITSIN & Italy & $\begin{array}{l}\text { Santa barbara, Sinna, } \\
\text { Sardena }\end{array}$ & 10 & 5 & 9.4473333 & 39.1613111 & uncultivated & 0.0603 & 0.033718182 & 0.733445455 & 0.172518182 & $\mathrm{CM}$ \\
\hline LIARA & Lebanon & Aramoun & 8 & 3 & 35.700579 & 34.020618 & uncultivated & 0.178883333 & 0.288166667 & 0.40995 & 0.12305 & \\
\hline LIENF & Lebanon & Saydit el Nourieh, Anfeh & 20 & 10 & 35.68203 & 34.30194 & uncultivated & 0.10534 & 0.1561 & 0.094145 & 0.6444 & \\
\hline LIFAN & Lebanon & Fanyou & 5 & 3 & 35.67538 & 34.063 & uncultivated & 0.11648 & 0.07442 & 0.04834 & 0.76076 & $\mathrm{EM}$ \\
\hline LIJBE & Lebanon & Jbeïl & 4 & 0 & 35.671 & 34.116947 & uncultivated & 0.14005 & 0.357025 & 0.178025 & 0.3249 & \\
\hline LIMAR & Lebanon & Mar Chaaya & 6 & 3 & 35.647109 & 33.894394 & uncultivated & 0.307066667 & 0.0957 & 0.057683333 & 0.53955 & \\
\hline LINAH & Lebanon & Nahr Ibrahim & 12 & 5 & 35.69636 & 34.0851 & uncultivated & 0.121216667 & 0.231766667 & 0.07755 & 0.569466667 & \\
\hline LIZEK & Lebanon & Zekrit valley & 14 & 3 & 35.621232 & 33.945713 & uncultivated & 0.175307143 & 0.251114286 & 0.06335 & 0.510207143 & \\
\hline MAAIT & Morocco & Aït Mansour oasis & 20 & 8 & -8.88119 & 29.55149 & uncultivated & 0.89101 & 0.046705 & 0.023005 & 0.039285 & SM \\
\hline MAASNI & Morocco & Asni, Haut atlas & 4 & 0 & -7.972671 & 31.222189 & uncultivated & 0.48925 & 0.05135 & 0.291575 & 0.167825 & \\
\hline MADA & Morocco & Village de pêche de Dalia & 11 & 3 & -5.4772 & 35.90411 & cultivated & 0.060122222 & 0.533766667 & 0.252266667 & 0.153855556 & \\
\hline MAIMO & Morocco & Imouzzer des Ida-Outanane & 11 & 6 & -9.23713 & 30.73312 & cultivated & 0.722890909 & 0.069618182 & 0.087263636 & 0.120227273 & SM \\
\hline
\end{tabular}




\begin{tabular}{|c|c|c|c|c|c|c|c|c|c|c|c|c|}
\hline MAIMO2 & Morocco & Imouzzer des Ida-Outanane & 20 & 7 & -9.4956 & 30.6557 & cultivated & 0.818785 & 0.06206 & 0.062775 & 0.05638 & SM \\
\hline MAKEL & Morocco & Oued Laou canyon & 18 & 8 & -5.22779 & 35.29865 & cultivated & 0.056188889 & 0.16455 & 0.149683333 & 0.629572222 & \\
\hline МАКНА & Morocco & Entre Dalia et Tetouan & 10 & 7 & -5.51225 & 35.6758 & cultivated & 0.11929 & 0.17397 & 0.12556 & 0.58119 & \\
\hline MALAO & Morocco & Oued Laou & 21 & 6 & -5.16468 & 35.39042 & cultivated & 0.027333333 & 0.352252381 & 0.478790476 & 0.141619048 & \\
\hline MALIL & Morocco & $\begin{array}{l}\text { Oued Mliliah, entre } \\
\text { Chefchaouen et Ouazanne }\end{array}$ & 10 & 0 & -5.3539 & 35.0429 & cultivated & 0.09656 & 0.21109 & 0.2047 & 0.48764 & \\
\hline MAOEJ & Morocco & $\begin{array}{l}\text { Oued ElJehba, proximité } \\
\text { village de Smih }\end{array}$ & 10 & 5 & -4.70325 & 35.16908 & cultivated & 0.04878 & 0.12083 & 0.16229 & 0.66809 & \\
\hline MAOUD & Morocco & Douar Oudjgal & 10 & 4 & -9.28211 & 29.75888 & cultivated & 0.62182 & 0.16007 & 0.07976 & 0.13836 & \\
\hline MAOUM & Morocco & Assif Oumarhouz canyon & 23 & 9 & -9.26054 & 29.7491 & uncultivated & 0.663609091 & 0.142127273 & 0.082231818 & 0.112036364 & \\
\hline MAOUR & Morocco & Ourika valley & 2 & 3 & -7.756 & 31.351 & cultivated & 0.85255 & 0.09255 & 0.03295 & 0.02195 & SM \\
\hline MAPAR & Morocco & Paradise Valley & 20 & 5 & -9.54509 & 30.56227 & uncultivated & 0.766205 & 0.056195 & 0.074855 & 0.10273 & SM \\
\hline MARTA & Morocco & $\begin{array}{l}\text { Between Tafraout and } \\
\text { Aittmansour }\end{array}$ & 11 & 7 & -8.94341 & 29.63326 & cultivated & 0.780527273 & 0.059090909 & 0.101018182 & 0.059372727 & SM \\
\hline MATAL & Morocco & $\begin{array}{l}\text { Oued Laou near Talembote } \\
\text { village }\end{array}$ & 15 & 6 & -5.21348 & 35.29823 & cultivated & 0.07902 & 0.082806667 & 0.217173333 & 0.621 & \\
\hline MATAN & Morocco & Near Aït Baha village & 19 & 0 & -9.21047 & 29.94297 & cultivated & 0.5896 & 0.154463158 & 0.091889474 & 0.164042105 & \\
\hline MATAR & Morocco & Near Aouguenz village & 19 & 10 & -9.20208 & 29.84102 & uncultivated & 0.758536842 & 0.108142105 & 0.070226316 & 0.063105263 & SM \\
\hline MATAS & Morocco & Oued Laou & 0 & 5 & -5.16468 & 35.39042 & cultivated & NA & NA & NA & NA & \\
\hline MATIZ & Morocco & Tiznit & 17 & 15 & -9.683611 & 29.689722 & cultivated & 0.596652941 & 0.160264706 & 0.087876471 & 0.155211765 & \\
\hline MAZIN & Morocco & Zinat & 11 & 6 & -5.39234 & 35.43856 & cultivated & 0.164645455 & 0.167654545 & 0.105054545 & 0.562636364 & \\
\hline PORBEN & Portugal & Benagil & 20 & 3 & -8.423525 & 37.090124 & cultivated & 0.064806667 & 0.084986667 & 0.785793333 & 0.064413333 & $\mathrm{CM}$ \\
\hline PORVIL & Portugal & Vila Lara & 15 & 1 & -8.391454 & 37.095663 & cultivated & 0.105573333 & 0.185 & 0.50244 & 0.206966667 & \\
\hline TURKO & Turquie & Köprülü canyon, Anthalya & 10 & 5 & 31.1808333 & 37.1922222 & uncultivated & 0.04691 & 0.04755 & 0.10796 & 0.79758 & EM \\
\hline
\end{tabular}


APPENDIX S2 Extended material and methods, Genbank and Dryad data accessions.
A) Amplification of plastid markers
B) Amplification, cloning and sequencing of sucrose synthase gene (SUSY)
C) Divergence time estimation analyses
D) Microsatellite genotyping
E) Coalescent simulations and prior distribution
F) Survey of palaeobotanical literature
G) Carob tree generation time 


\section{A) Amplification of plastid markers}

Total DNA was extracted from ca. $25 \mathrm{mg}$ of dry leaves stored in silica gel using the NucleoSpin Plant II kit (MACHEREY-NAGEL SARL, France). DNA concentrations were normalized to $5 \mathrm{ng} / \mu 1$.

Specific primers for four plastid regions were designed for Ceratonia species: matK gene (F: CCTTCGATACTGGGTGAAAGAT, R: CCAGACCGGCTTACTAATGGG), ccSA-ndhD spacer (F: GTGGCCTCTATGGGCTTTCT, R: TCCGTTGACAAGGTCGAAGC), rpl32-trnL spacer (F: TCTCGACCCAATAAAAACCC, R: AAGGTACCGTTGGAACTAGA) and psbD-trnT spacer (F: ATTCAATGGGTTAGGTCCAC, R: CCCTTTTAACTCAGTGGTAG). The PCR mix contained $5 \mu \mathrm{L}$ of $5 \mathrm{x}$ buffer, $2 \mu \mathrm{L} \mathrm{MgCl} 225 \mathrm{mM}, 4 \mu \mathrm{L}$ of dNTPs $(1.25 \mathrm{mM}), 1 \mu \mathrm{L}$ of each primer $10 \mathrm{uM}, 0,2 \mu \mathrm{L}$ of GoTaq, $1 \mu \mathrm{L}$ of DNA and the total volume was $25 \mu \mathrm{L}$. PCR program consisted on $5 \min$ at $94^{\circ} \mathrm{C}$; followed by 30 cycles of $30 \mathrm{~s}$ at $94^{\circ} \mathrm{C}, 30 \mathrm{~s}$ at $52^{\circ} \mathrm{C}$ and $1 \mathrm{~min}$ at $72^{\circ} \mathrm{C}$, and a final elongation step of 7 $\min$ at $72^{\circ} \mathrm{C}$. All PCRs were carried out in a Mastercycler nexus GSX1 thermocycler (Eppendorf) and the existence of amplicons was corroborated in agarose gels. All sequences were deposited in Genbank (Table S2.1).

TABLE S2.1: Genbank accessions of plastid haplotypes found within Ceratonia siliqua and $C$. oreothauma for each marker.

\begin{tabular}{|c|c|c|c|c|c|c|c|}
\hline Haplotypes & $\begin{array}{c}\text { ccsa-ndhD } \\
\text { spacer }\end{array}$ & matk & $\begin{array}{c}\text { psbD-trnT } \\
\text { spacer }\end{array}$ & $\begin{array}{c}\text { rpl32-trnL } \\
\text { spacer }\end{array}$ & Taxon & Country & Provenance \\
\hline 1 & MK564073 & MK564064 & MK532008 & MK532022 & C. siliqua & Spain & ESBEN \\
\hline 2 & MK564074 & MK564065 & MK532009 & MK532023 & C. siliqua & Spain & ESGRA \\
\hline 3 & MK564075 & MK564066 & MK532010 & MK532024 & C. siliqua & Morocco & MAPAR \\
\hline 4 & MK564076 & MK564067 & MK532011 & MK532025 & C. siliqua & France & FRTLN \\
\hline 5 & MK564077 & MK564068 & MK532012 & MK532026 & C. siliqua & Italy & SIPATT \\
\hline 6 & MK564078 & MK564069 & MK532013 & MK532027 & C. siliqua & Lebanon & Jbeil \\
\hline 7 & MK564079 & MK564070 & MK532014 & MK532028 & C. oreothauma & Oman & OMBG \\
\hline 8 & MK564080 & MK564071 & MK532015 & MK532029 & C. oreothauma & Oman & E00023536 \\
\hline 9 & MK564081 & MK564072 & MK532016 & MK532030 & C. oreothauma & Yemen & E00277381 \\
\hline
\end{tabular}

The concatened alignment of the four markers is available in Dryad Digital Repository (https://doi.org/10.5061/dryad.k7m020r). The order is ccsa-ndhD (387 bp long), the matk (624 bp long), the psbDtrnT (314 bp long) and rpl32-trnL (164 bp long). 


\section{B) Amplification, cloning and sequencing of sucrose synthase gene (SUSY)}

The nuclear sucrose synthase (SUSY) gene was amplified in two samples of Ceratonia siliqua and one sample of Ceratonia oreothauma by using the primers designed by Manzanilla et al. (2012). The amplicon size was about $700 \mathrm{bp}$. The PCR mix contained $5 \mu \mathrm{L}$ of $5 \mathrm{x}$ buffer, $1.5 \mu \mathrm{L} \mathrm{MgCl} 225 \mathrm{mM}, 4$ $\mu \mathrm{L}$ of dNTPs $(1.25 \mathrm{mM}), 0.41 .25 \mu \mathrm{L}$ of each primer $(10 \mathrm{uM}), 0,2 \mu \mathrm{L}$ of GoTaq, $1 \mu \mathrm{L}$ of DNA in a total volume was $25 \mu \mathrm{L}$. The PCR program consisted on $5 \mathrm{~min}$ at $94^{\circ} \mathrm{C}$; followed by 30 cycles of $30 \mathrm{~s}$ at $94^{\circ} \mathrm{C}, 30 \mathrm{~s}$ at $54^{\circ} \mathrm{C}$ and $45 \mathrm{~s}$ at $72^{\circ} \mathrm{C}$, and a final elongation step of $7 \mathrm{~min}$ at $72^{\circ} \mathrm{C}$. All PCRs were carried out in a Mastercycler nexus GSX1 thermocycler (Eppendorf). Amplicons of the expected size were cut from an agarose gel and purified using the Wizard SV Gel kit (Promega). Purified bands were then cloned in a pGEMt A1360 plasmid vector (Promega) and eight clones per amplicon were sequenced. Reverse and forward chromatograms were assembled and revised with Sequencher (version 4.5, GeneCodes Corp., Ann Arbor, MI, USA) and alignments were performed in MEGA 7. Genbank accessions of SUSY sequences are indicated in Table S2.2.

TABLE S2.2: Genbank accessions of carob SUSY sequences used for divergence time analyses

\begin{tabular}{lllll}
\hline Sample & Country & Provenance & SUSY 1 & SUSY 2 \\
\hline $\begin{array}{l}\text { Ceratonia siliqua } \\
\text { sample 1 }\end{array}$ & Spain & Ojen, ESOJ365 & MK602656 & MK634743 \\
$\begin{array}{l}\text { Ceratonia siliqua } \\
\text { sample 2 }\end{array}$ & Lebanon & Aramoun, LIARA205 & MK602657 & MK634744 \\
$\begin{array}{l}\text { Certonia } \\
\text { oreothauma }\end{array}$ & Oman & E00023536 & MK602658 & MK634745 \\
\hline
\end{tabular}

\section{C) Divergence time estimation analyses}

SUSY network was confidently split into two different paralogues and subsequently two matrices were elaborated corresponding with the copies already detected by Manzanilla (2012): SUSY1 and SUSY2. We used the available sequences at Genbank for matK and SUSY for other Leguminosae species to carry out divergence time estimation analyses. The alignment used for divergence time analysis is available in Dryad Digital Repository (https://doi.org/10.5061/dryad.k7m020r).

The best nucleotide substitution model was calculated with Jmodeltest2: GTR+G for matK, HKY+I+G for SUSY1 and SUSY2. The introns were removed due to difficulties with the alignments. Heterogeneity tests were calculated to estimate the incongruence between matrices following Viruel et al. (2018). Significant differences in topology were determined for both copies of SUSY1 and incongruences was tested by eye among the phylogenetic trees obtained for independent analyses.

Divergence times were estimated using a Bayesian relaxed-clock approach implemented in BEAST v. 1.8.3 (Drummond and Rambaut, 2007). Both concatenated and independent data sets were run under the selected substitution models, a Yule speciation process prior, and an uncorrelated lognormal molecular clock. The ucld.mean was assigned a uniform prior distribution of initial $=1 \mathrm{e}-4$, lower $=1 \mathrm{e}-$ 4 , upper $=1 \mathrm{e}-1$ value (Viruel et al. 2016). Two MCMC chains were run for 100 million generations, sampling parameters every 10,000th generations, and convergence was evaluated by the effective sampling size (ESS > 200) in TRACER v. 1.6. Post-burnin trees were summarized into a maximum clade credibility tree with mean values and $95 \%$ confidence intervals using TREEANNOTATOR v. 1.8.1.

We used four calibration points. A primary calibration was based on a fossil record of Ceratonia attributed to Ceratonia emarginata Heer from CE Europe and dated at Mid to Late Oligocene 
(Palamarev 1989). This fossil was used to calibrate the Ceratonia stem node with a lognormal prior distribution (mean in real space $=28.1$, stdev $=0.2$ ). Three secondary calibrations based on a previous divergence time estimation study (Lavin et al. 2005) were also used with a normal prior distribution: i) $54.0 \pm 3.4$ assigned to the Umtiza stem node, ii) $58.6 \pm 0.25$ applied to the papilionoid stem node, and iii) $59 \pm 0.2$ set to the legume stem node.

\section{References:}

Lavin, M., Herendeen, P. S., \& Wojciechowski, M. F. (2005). Evolutionary rates analysis of Leguminosae implicates a rapid diversification of lineages during the tertiary. Systematic biology, 54, 575-594.

Manzanilla, V., \& Bruneau, A. (2012) Phylogeny reconstruction in the Caesalpinieae grade (Leguminosae) based on duplicated copies of the sucrose synthase gene and plastid markers. Molecular Phylogenetics and Evolution, 65, 149-162

Palamarev E. (1989) Paleobotanical evidences of the Tertiary history and origin of the Mediterranean, sclerophyll dendroflora. Plant Systematics and Evolution, 162, 93-107.

Viruel, J., Segarra-Moragues, J. G., Raz, L., Forest, F., Wilkin, P., Sanmartin, I., \& Catalan, P. (2016). Late Cretaceous-Early Eocene origin of yams (Dioscorea, Dioscoreaceae) in the Laurasian Palaearctic and their subsequent Oligocene-Miocene diversification. Journal of Biogeography, 43, 750-762.

Viruel, J., Forest, F., Paun, O., Chase, M. W., Devey, D., Sousa Couto, R., Segarra-Moragues, J. G., Catalan, P., \& Wilkin, P. (2018). A nuclear Xdh phylogenetic analysis of yams (Dioscorea: Dioscoreaceae) congruent with plastid trees reveals a new Neotropical lineage. Botanical Journal of the Linnean Society, 187, 232-246.

\section{D) Microsatellite genotyping}

Viruel et al. (2018) described the laboratory and bioinformatic methods to amplify, sequence and genotype the 17 markers used in this study. The SSR data and results of STRUCTURE are available in Dryad Digital Repository (https://doi.org/10.5061/dryad.k7m020r).

\section{References:}

Viruel, Juan, et al. 2018 Advances in genotyping microsatellite markers through sequencing and consequences of scoring methods for Ceratonia siliqua (Leguminosae). Applications in Plant Sciences 6.12: e01201. https://doi.org/10.1002/aps3.1201 


\section{E) Coalescent simulations and prior distribution}

All simulations were done in Fastsimcoal 2.6 (Excoffier et al., 2011), summary statistics used were computed using ArlSumStat in Arlequin (Excoffier \& Lischer, 2010). Fifty diploid individuals per population were randomly selected to compute the summary statistics.

Population sizes $(\mathrm{N})$ were drawn from a uniform distribution [lower bound 10; higher bound 10000 individuals]. Nodes timings from a uniform distribution [1; 10000]; Tanc is the most ancient node, T2 the second node and $\mathrm{T} 1$ the third node forward in time. We enforced Tanc>T2>T1 for the ERH, Tanc $>\mathrm{T} 1$ and Tanc>T2 for the TRH. Generalized stepwise mutation (GSM) model was used for microsatellite mutation model (Estoup et al 2002). SSR mutation rate (mutssr) was drawn from a LogUnif distribution $[0.0001 ; 0.0008]$, and the probability that the SSR size change for more than one repetition per mutation $(\mathrm{P})$ was drawn from a log uniform distribution $[0.1 ; 0.3]$, according to reviews (Estoup et al., 2002; Petit \& Hampe 2006).

\section{References:}

Estoup, A., Jarne, P., \& Cornuet, J. M. (2002). Homoplasy and mutation model at microsatellite loci and their consequences for population genetics analysis. Molecular ecology, 11, 1591-1604.

Excoffier, L., \& Lischer, H. E. (2010). Arlequin suite ver 3.5: a new series of programs to perform population genetics analyses under Linux and Windows. Molecular ecology resources, 10, 564-567

Excoffier, L., \& Foll, M. (2011). Fastsimcoal: a continuous-time coalescent simulator of genomic diversity under arbitrarily complex evolutionary scenarios. Bioinformatics, 27, 1332-1334

Petit, R. J., \& Hampe, A. (2006). Some evolutionary consequences of being a tree. Annual Review of Ecology Evolution and Systematics, 37, 187-214.

Table S2.3: Parameters and prior used for coalescent simulation in FASTSIMCOAL 2.6

\begin{tabular}{llll}
\hline Parameter & Range & Distribution & Meaning \\
\hline T1 & $1-10000$ & uniform & First divergence from present \\
T2 & $1-10000$ & uniform & Second divergence from present \\
Tanc & $1-10000$ & uniform & Ancestral divergence \\
NSM & $10-10000$ & uniform & Current effective size SM \\
NSS & $10-10000$ & uniform & Current effective size SS \\
NCM & $10-10000$ & uniform & Current effective size CM \\
NEM & $10-10000$ & uniform & Current effective size EM \\
Nanc & $10-10000$ & uniform & Ancestral effective size \\
mutssr & $0.0001-0.0008$ & loguniform & Mutation rate per locus \\
$\boldsymbol{p}$ & $0.1-0.3$ & loguniform & Parameter for the GSM model \\
\hline
\end{tabular}


Table S2.4: Summary statistics of genetic diversity based on SSR markers used for statistical phylogeography of Ceratonia siliqua. Only the population having membership above the median of the cluster were kept. SM= South Morocco, $\mathrm{SS}=$ South Spain, $\mathrm{CM}=$ central Mediterranean, $\mathrm{EM}=$ eastern Mediterranean. $K$ is the mean number of alleles by locus, $H$ is the expected heterozygosity, Fst and $\delta \mu^{2}$ are two different indices of differentiation.

\begin{tabular}{lllllll}
\hline & SM & SS & CM & EM & mean & \\
\hline $\boldsymbol{K}$ & 5,06 & 4,53 & 4,53 & 4,06 & 4,54 & \\
$\mathbf{H}$ & 0.58 & 0.55 & 0.46 & 0.50 & 0.52 & \\
\hline & SS_CM & EM_CM & EM_SS & SM_CM & SM_SS & SM_EM \\
$\boldsymbol{F} \boldsymbol{s} \boldsymbol{t}$ & 0.14 & 0.06 & 0.12 & 0.10 & 0.08 & 0.11 \\
$\boldsymbol{\delta} \boldsymbol{\mu}^{2}$ & 1.42 & 0.32 & 1.64 & 1.50 & 0.77 & 1.65 \\
\hline Overall Fst & $10.2 \%$ & & & & & \\
\hline
\end{tabular}

\section{E) Carob Distribution Modelling}

Occurrence records of $C$. siliqua were gathered across its native range in the Mediterranean basin from several sources. We extracted information from the survey of phytosociological study by Baumel et al. (2018), we also collected the data available at the Global Biodiversity Information Facility (GBIF, https://www.gbif.org/) and we added the geographic coordinates of the populations sampled in this study (Table 1). We cleaned the dataset by discarding duplicates, records older than 1950 , records located in the sea, and those having integer coordinates or coordinates equal to zero. We tried to eliminate all occurrences coming from carob orchards. To avoid duplicates in further analyses, we kept only one record for each occupied 2.5 arc-minutes $(\sim 5 \mathrm{~km})$ grid cell covering the species range. The final dataset consisted in 619 occurrence points (available in Dryad Digital Repository: https://doi.org/10.5061/dryad.k7m020r).

We extracted the climatic variables at a 2.5 arc-min resolution from the version 1.4 of the Worldclim database (http://worldclim.org) for each of the occurrence points. To avoid multi-collinearity among the 19 bioclimatic variables, we selected only six based on a principal component analysis (PCA) and a correlation matrix (results not shown): temperature seasonality (BIO4), maximum temperature of the warmest month (BIO5), mean temperature of the wettest (BIO8) and coldest quarters (BIO11), precipitation of both the warmest (BIO18) and coldest quarter (BIO19). As different species distribution modelling techniques may produce divergent predictions, we used a consensus approach (Marmion et al., 2009). We ran four different probabilistic models with the biomod2 package in $\mathrm{R}$ (Thuiller et al., 2009): Generalized Additive Model (GAM), Generalized Boosting Model (GBM), RandomForest (RF), and MaxEnt. These statistical models are calibrated with both presence and absence (or background for MaxEnt) points. No true absence information is available for $C$. siliqua across its range, so we ran the models with five different sets of 5,000 pseudo-absence/background points randomly sampled across the study area (Barbet-Massin et al., 2012). We assigned the same six climatic variables to these points as for occurrence records. We used $70 \%$ of the dataset to calibrate the models and the remaining $30 \%$ to evaluate them. This data-splitting strategy was repeated ten times and we evaluated the model predictive accuracy using two different indices: the True Skill Statistics (TSS, Allouche et al., 2006) 
and the area under the Receiver Operating Characteristic curve (ROC, Hanley \& McNeil, 1982). A total of 400 distribution models was ran (four algorithms, five pseudo-absence/background selections, two evaluation indices, and ten repetitions). The distribution of $C$. siliqua was projected under current, MidHolocene ( 6,000 years ago), Last Glacial Maximum (LGM; 22,000 years ago), and Last Inter-Glacial (LIG; 120,000 - 140,000 years ago) climatic conditions. Mid-Holocene and LGM climate layers were generated by the Paleoclimate Modelling Intercomparison Project (Braconnot et al., 2007) and LIG ones by Otto-Bliesner et al. (2006). All were downloaded from Worldclim: Mid-Holocene and LGM data at a 2.5 arc-min resolution and LIG maps at a 30 arc-seconds resolution. The latter were then upscaled to 2.5 arc-min using the aggregate function from the raster package in $\mathrm{R}$. We then projected the species distribution at Mid-Holocene and LGM according to three Global Circulation Models (GCMs); CCSM4, MIROC-ESM, and MPI-ESM-P and at the LIG according to projections from OttoBliesner et al. (2006). Finally, we generated one consensus map for each time slice and GCM by computing a mean of the 400 maps obtained previously weighted by their respective evaluation score (i.e. TSS score) and discarding models with TSS $<0.6$ and ROC $<0.8$. All the results are shown in Appendix 3 Figure S3.7.

\section{References:}

Allouche, O., Tsoar, A., \& Kadmon, R. (2006). Assessing the accuracy of species distribution models: prevalence, kappa and the true skill statistic (TSS). Journal of applied ecology, 43, 1223-1232.

Barbet-Massin, M., Jiguet, F., Albert, C. H., \& Thuiller, W. (2012). Selecting pseudo-absences for species distribution models: how, where and how many? Methods in Ecology and Evolution, 3, 327338.

Baumel A., Mirleau P., Viruel J., Kharrat M.B.D., Malfa S.L., Ouahmane L., ... Médail F. (2018) Assessment of plant species diversity associated with the carob tree (Ceratonia siliqua, Fabaceae) at the Mediterranean scale. Plant Ecology and Evolution, 151, 185-193.

Braconnot, P., Otto-Bliesner, B., Harrison, S., Joussaume, S., Peterchmitt, J. Y., Abe-Ouchi, A., ... \& Kageyama, M. (2007). Results of PMIP2 coupled simulations of the Mid-Holocene and Last Glacial Maximum-Part 1: experiments and large-scale features. Climate of the Past, 3, 261-277.

Hanley, J. A., \& McNeil, B. J. (1982). The meaning and use of the area under a receiver operating characteristic (ROC) curve. Radiology, 143(1), 29-36.

Marmion, M., Parviainen, M., Luoto, M., Heikkinen, R. K., \& Thuiller, W. (2009). Evaluation of consensus methods in predictive species distribution modelling. Diversity and Distributions, 15, 5969.

Otto-Bliesner, B. L., Marshall, S. J., Overpeck, J. T., Miller, G. H., \& Hu, A. (2006). Simulating Arctic climate warmth and icefield retreat in the last interglaciation. Science, 311, 1751-1753.

Thuiller, W., Lafourcade, B., Engler, R., \& Araújo, M. B. (2009). BIOMOD-a platform for ensemble forecasting of species distributions. Ecography, 32, 369-373 


\section{F) Survey of palaeobotanical literature}

Concerning the oldest occurrences (i.e. those prior to $3 \mathrm{Ma}$ ), there are nine localities with Ceratonia macro-remains (leaf imprints) and eighteen localities with pollen grains (Table S2.5).

For most of the specimens older than $12 \mathrm{Ma}$, the leaf imprints have been attributed to the fossil species C. emarginata Al. Braun (localities $\left.\mathrm{n}^{\circ} 55,51,47,44\right)$ or C. vetusta Sap. (locality $\mathrm{n}^{\circ} 54$ ), which are considered very close to the modern species C. siliqua (De Saporta, 1863; Palamarev et al., 2000; Akgün et al., 2004; Hably, 2006). Other leaf imprint of C. emarginata was found in Oeningen (Germany) dated in the 'Neogene' (Collection of Palaeontology of the National Museum of Natural History of Paris), the lack of precision in this dating prevented us to include it in Fig. 4 and Table S2.5. Those specimens younger than $4 \mathrm{Ma}$ are all attributed to the modern C. siliqua, being wood charcoals or burned pods.

Considering the localities older than $1 \mathrm{Ma}$, fossil pollen grains ascribed to Ceratonia are very rare. Photographs from seven specimens are shown Fig. S2.1 (views 14 to 28), distributed from 15 (Langhian) to $1.4 \mathrm{Ma}$ (Calabrian). They show the same morphology as the modern pollen of C. siliqua and a similar variability in size (Fig. S2.1: views $1-13$ ). They significantly differ from the pollen of the sister species $C$. oreothauma Hillc., Lewis \& Verde in the number of apertures and surface ornamentation (Ferguson, 1980).

Scarcity of carob pollen grains is explained by the insect pollination prevalent mode of the plant that results in its under-representation as observed in modern pollen floras (Rossignol, 1969; Weinstein, 1981; Bottema \& Sarpaki, 2003). This handicap is accentuated by the pollen transport supplied by rivers in most of the localities deposited in marine coastal conditions. Among the two alone lacustrine localities, Rubielos de Mora ( $\left.\mathrm{n}^{\circ} 50\right)$ and Camerota ( $\left.\mathrm{n}^{\circ} 26\right)$, the latter shows very propitious conditions to have recorded fossil pollen grains of Ceratonia by the very small size of the palaeo-lake and its deposition context at a glacial-interglacial transition. These peculiarities made of Camerota an exceptional site with the expression of an initial Oleo-Ceratonion palaeo-vegetation as shown in the main text of the paper. All the pollen localities younger than $1 \mathrm{Ma}$ (Table S2.5 $\mathrm{n}^{\circ} 24$ to 1 ) show very low percentages of C.siliqua except a sample from the Bolomar Cave (locality n ${ }^{\circ} 24$ ). 


\section{Modern pollen grains}

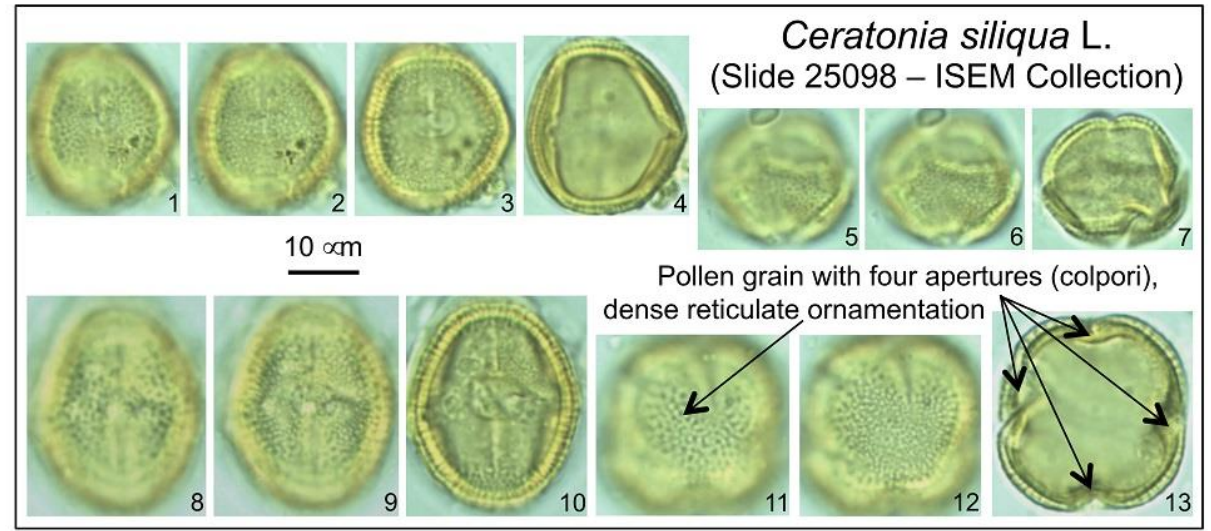

Fossil pollen grains

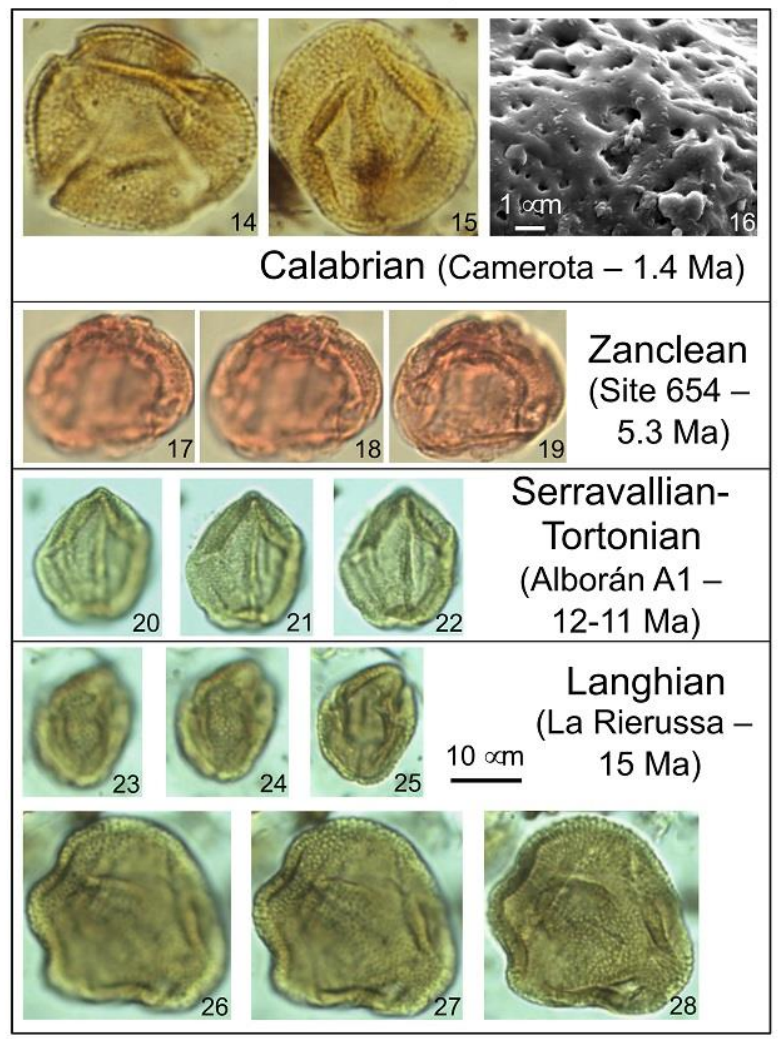

Figure S2.1: Modern pollen grains of Ceratonia siliqua L. and examples of fossil pollen grains ascribed to Ceratonia. The scale bar $(10 \mu \mathrm{m})$ is the same for all the photographs at light microscope (X 1000), it differs (1 $\mu \mathrm{m}$ ) for view 16 at scanning electron microscope (X 10000). Description of morphological terms refers to Punt $e t$ al., (2007).

Images 1 - 13, Modern pollen grains of Ceratonia siliqua L. (slide 25098 from the Collection of the Institut des Sciences de l'Evolution de Montpellier, ISEM - specimen from Lebanon at the Herbarium of the National Museum of Natural History in Paris).

$1-4$, LO-analysis of a small pollen in equatorial view.

1 , Focus on the reticulate ornamentation of ectexine. 
2, Focus on the base of luminae.

3 , Focus on a colporus (front view).

4 , Focus on two colpori (profile view) and optical section. The fourth colporus is visible in transparency in the middle part of the pollen.

$5-7$, LO-analysis of a small pollen in polar view.

5 , Focus on the reticulate ornamentation of ectexine.

6 , Focus on the base of luminae.

7 , Focus on the four colpori and optical section.

$8-10$, LO-analysis of a large pollen in equatorial view.

8 , Focus on the reticulate ornamentation of ectexine.

9 , Focus on the base of luminae and a colporus (front view).

10 , Focus on two colpori (profile view) and optical section. The fourth colporus is visible in transparency in the middle part of the pollen.

11 - 13, LO-analysis of a large pollen in polar view.

11 , Focus on the reticulate ornamentation of ectexine.

12 , Focus on the base of luminae.

13, Focus on the four colpori and optical section.

Images $14-27$, Fossil pollen grains ascribed to Ceratonia.

14 - 16, Large pollen from Camerota in Southern Italy (Calabrian, Early Pleistocene), old of 1.4 Ma (Suc \& Popescu, 2005).

14, Polar view of a pollen grain showing the reticulate ornamentation of ectexine, the four colpori and optical section.

15 , Equatorial view showing the reticulate ornamentation of ectexine, the base of luminae, and the four colpori.

16, Surface of a pollen grain at scanning electron microscope (for comparison with modern pollen of C. siliqua, see Fig. A from Ferguson, 1980).

17 - 19, LO-analysis of a medium-size pollen in equatorial view from Site 654 in the Western Tyrrhenian Sea (early Zanclean, Pliocene), old of 5.3 Ma (Popescu, unpublished).

17 , Focus on the reticulate ornamentation of ectexine.

18 , Focus on the base of luminae.

19, Focus on two colpori (front view).

20 - 22, LO-analysis of a small pollen in equatorial view from hole Alborán A1 in the Alborán Sea (Serravallian-Tortonian, Mid-Late Miocene), old of 12-11 Ma (Jiménez-Moreno \& Suc, 2007).

20 , Focus on the reticulate ornamentation of ectexine.

21 , Focus on the base of luminae and a colporus (front view).

22 , Focus on two colpori (profile view).

23 - 25, LO-analysis of a small pollen in equatorial view from La Rierussa section in Catalunya (Langhian, Mid-Miocene), old of 15 Ma (Jiménez-Moreno \& Suc, 2007).

23 , Focus on the reticulate ornamentation of ectexine.

24 , Focus on the base of luminae.

25, Focus on two colpori (profile view), the two other colpori are visible in transparency.

26 - 28, LO-analysis of a large pollen in a slantwise polar view from La Rierussa section in Catalunya (Langhian, Mid-Miocene), old of 15 Ma (Jiménez-Moreno \& Suc, 2007).

26 , Focus on the reticulate ornamentation of ectexine.

27 , Focus on the base of luminae.

28 , Survey of the four colpori.

On the basis of the LO-analysis method (i.e., successive focuses according to Lux vs. Obscuritas) at light microscope (Erdtman, 1952), the pollen grain of $C$. siliqua shows a homogenous morphology despite important variations in size $^{1}$ (Figs. 1 - 13). As described by Ferguson (1980), it is spheroidal

\footnotetext{
${ }^{1}$ Description of morphological terms refers to Punt et al. (2007).
} 
somewhat longiaxe (= prolate) with a 4-lobed outline in polar view, because of the occurrence of four apertures. Each aperture is a colporus made of a relatively long colpus in the ectexine (ectoaperture) and a relatively large porus elongated along the equatorial axis in the endexine (endoaperture). Each porus is bordered by a thin annulus. Endexine shows the same thickness than the semitectate ectexine. Ectexine ornamentation is a dense homobrochate reticulum with muri thinner than luminae. There is no margo along the colpi. $C$. siliqua has predominantly a tetracolporate pollen (i.e., with 4 colpori) whereas C. oreothauma has predominantly a tricolporate pollen (i.e., with 3 colpori) with a reticulum showing equal size of muri and luminae (Ferguson, 1980).

Pollen grain of Citrus (Rutaceae) is also tetracolporate and reticulate. It can be distinguished from that of Ceratonia siliqua by its thicker endexine, the occurrence of a thin margo and costae along the colpi, a thicker annulus around the pori, and an equal thickness of muri and luminae of the reticulum. 
Table S2.5. Summary of known fossil occurrences of Ceratonia from Oligocene to Middle Ages. Ages are indicated according to the chronostratigraphic charts in thousand years $(\mathrm{ka})$ or in million years $(\mathrm{Ma}) . \mathrm{p}=$ pollen grains; $\mathrm{m}=$ macroremains (leaves, fruits, seeds, wood).

\begin{tabular}{|c|c|c|c|c|c|c|}
\hline $\begin{array}{c}\text { No } \\
\text { (Fig.4) }\end{array}$ & Age & ka & $\begin{array}{c}\text { Fossil } \\
\text { type }\end{array}$ & Locality & Coordinates & Reference \\
\hline 1 & Middle Ages & 0.7 & $\mathrm{~m}$ & Rock of Ifach, Calp, SE. Spain & $38.6381^{\circ} \mathrm{N}-0.0736^{\circ} \mathrm{E}$ & Ntinou et al., 2013 \\
\hline 2 & Middle Ages & 1.9 & $\mathrm{p}$ & Psatha, Corinth Gulf, Greece & $38.1068^{\circ} \mathrm{N}-23.2215^{\circ} \mathrm{E}$ & Jahns, 2003 \\
\hline 3 & Antiquity & 2 & $\mathrm{~m}$ & Herculanum, S. Italy & $40.8060^{\circ} \mathrm{N}-14.3474^{\circ} \mathrm{E}$ & Meyer, 1980 \\
\hline 4 & Antiquity & 3 & $\mathrm{p}$ & Ein Feshkha, Jericho, West Bank & $31.7221^{\circ} \mathrm{N}-35.4612^{\circ} \mathrm{E}$ & Neumann et al., 2007 \\
\hline 5 & Antiquity & 3 & $\mathrm{p}$ & Katochi, W. Greece & $38.4296^{\circ} \mathrm{N}-21.1621^{\circ} \mathrm{E}$ & Fouache et al., 2005 \\
\hline 6 & Antiquity & 3 & $\mathrm{p}$ & Lake Hula, N. Israel & $33.1065^{\circ} \mathrm{N}-35.6057^{\circ} \mathrm{E}$ & Van Zeist et al., 2009 \\
\hline 7 & Antiquity & 3.1 & $\mathrm{p}$ & Mljet, S. Dalmatian Islands & $42.7792^{\circ} \mathrm{N}-17.3472^{\circ} \mathrm{E}$ & Jahns \& van den Bogaard, 1998 \\
\hline 8 & Antiquity & 3.3 & $\mathrm{p}$ & Dalmatian Islands & $43.0541^{\circ} \mathrm{N}-16.7964^{\circ} \mathrm{E}$ & Šoštarić, 2005 \\
\hline 9 & Antiquity & 3.5 & $\mathrm{p}$ & Kournas, Crete & $35.32^{\circ} \mathrm{N}-24.2909^{\circ} \mathrm{E}$ & Bottema \& Sarpaki, 2003 \\
\hline 10 & Holocene & 4 & $\mathrm{p}$ & Laguna de Zoñar, S. Spain & $37.4814^{\circ} \mathrm{N}-4.6938^{\circ} \mathrm{W}$ & Martín-Puertas et al., 2008 \\
\hline 11 & Holocene & 4 & $\mathrm{~m}$ & Bastida de Totana, SE. Spain & $38.7592^{\circ} \mathrm{N}-1.5597^{\circ} \mathrm{W}$ & Núñez et al., 1988 \\
\hline 12 & Holocene & 6 & $\mathrm{p}$ & Addaia lagoon, Minorca, E. Spain & $39.9898^{\circ} \mathrm{N}-4.2060^{\circ} \mathrm{E}$ & Servera-Vives et al., 2018 \\
\hline 13 & Holocene & 7.5 & $\mathrm{~m}$ & Cave V/49, Jebel Quruntul, N. Israel & $31.8718^{\circ} \mathrm{N}-35.4310^{\circ} \mathrm{E}$ & Melamed, 2002 \\
\hline 14 & Holocene & 7.5 & $\mathrm{~m}$ & Aktopraklık, NW. Turkey & $40.1744^{\circ} \mathrm{N}-28.7701^{\circ} \mathrm{E}$ & Schroedter \& Nelle, 2015 \\
\hline 15 & Holocene & 11 & $\mathrm{p}$ & Ifri Oudadane, N. Morocco & $35.2056^{\circ} \mathrm{N}-3.2978^{\circ} \mathrm{W}$ & Zapata et al., 2013 \\
\hline 16 & Holocene & 11 & $\mathrm{~m}$ & Tell es-Sultan, West Bank & $31.8046^{\circ} \mathrm{N}-35.4856^{\circ} \mathrm{E}$ & Asouti et al., 2015 \\
\hline 17 & Earliest Holocene & 11.3 & $\mathrm{p}$ & Salada Mediana, Ebro Valley, NE. Spain & $41.5018^{\circ} \mathrm{N}-0.7326^{\circ} \mathrm{W}$ & González-Sampériz et al., 2004 \\
\hline 18 & Late Pleistocene & 12 & $\mathrm{~m}$ & Jericho, West Bank & $32.1304^{\circ} \mathrm{N}-35.7632^{\circ} \mathrm{E}$ & Western, 1971 \\
\hline 19 & Late Pleistocene and Antiquity & 35 to 7 , and ca. 2 & $\mathrm{p}$ & Nahr Ibrahim Cave, Lebanon & $34.0662^{\circ} \mathrm{N}-35.6452^{\circ} \mathrm{W}$ & Leroi-Gourhan, 1973, 1980 \\
\hline 20 & Late Pleistocene & 65 & $\mathrm{p}$ & Nahal Mahanayeem Outlet, N. Israel & $33.0332^{\circ} \mathrm{N}-35.6313^{\circ} \mathrm{E}$ & Aharonovich et al., 2014 \\
\hline 21 & Mid- to Late Pleistocene & 350 to 40 & $\mathrm{p}$ & Core PRGL1-4, NW. Mediterranean & $42.6930^{\circ} \mathrm{N}-3.8416^{\circ} \mathrm{E}$ & Suc et al., 2018 \\
\hline 22 & Late Pleistocene & 112 to 62 & $\mathrm{p}$ & Lazaret Cave, SE. France & $43.6903^{\circ} \mathrm{N}-7.2948^{\circ} \mathrm{E}$ & Lebreton et al., 2007 \\
\hline 23 & End of the Mid-Pleistocene & ca. 125 & $\mathrm{p}$ & Batroum, Lebanon & $34.2617^{\circ} \mathrm{N}-35.6605^{\circ} \mathrm{W}$ & Leroi-Gourhan, 1973, 1980 \\
\hline \multirow[t]{2}{*}{24} & Mid-Pleistocene & 600 to 120 & $\mathrm{p}$ & Bolomar Cave, SE. Spain & $39.0594^{\circ} \mathrm{N}-0.2416^{\circ} \mathrm{W}$ & Ochando et al., 2019 \\
\hline & Age & Ma & & & & \\
\hline 25 & Early Pleistocene & 1 & $\mathrm{p}$ & Vallonnet Cave, SE. France & $43.7646^{\circ} \mathrm{N}-7.4702^{\circ} \mathrm{E}$ & $\begin{array}{l}\text { Renault-Miskovsky \& Girard, } \\
1978\end{array}$ \\
\hline 26 & $\begin{array}{l}\text { Calabrian, } \\
\text { Early Pleistocene }\end{array}$ & 1.4 & $\mathrm{p}$ & Camerota, S. Italy & $40.0386^{\circ} \mathrm{N}-15.3707^{\circ} \mathrm{E}$ & Brenac, 1984 \\
\hline 27 & $\begin{array}{l}\text { Gelasian, } \\
\text { Early Pleistocene }\end{array}$ & 2.3 & $\mathrm{p}$ & WellAndalucia G1, SW. Mediterranean & $36.3963^{\circ} \mathrm{N}-4.7522^{\circ} \mathrm{W}$ & Feddi et al., 2011 \\
\hline 28 & $\begin{array}{l}\text { Gelasian, } \\
\text { Early Pleistocene }\end{array}$ & 2.5 to & $\mathrm{p}$ & Crotone, S. Italy & $39.0347^{\circ} \mathrm{N}-17.1524^{\circ} \mathrm{E}$ & Combourieu-Nebout, 1990 \\
\hline 29 & Piacenzian, Late Pliocene & 3.5 & $\mathrm{~m}$ & Ichkeul Lake, N. Tunisia & $37.2028^{\circ} \mathrm{N}-9.6623^{\circ} \mathrm{E}$ & Arambourg et al., 1952 \\
\hline 30 & Zanclean, Early Pliocene & 3.8 & $\mathrm{p}$ & Well Tarragona E2, NW. Mediterranean & $40.8425^{\circ} \mathrm{N}-1.1458^{\circ} \mathrm{E}$ & Bessais \& Cravatte, 1988 \\
\hline 31 & Zanclean, Early Pliocene & 4.95 & $\mathrm{p}$ & Husnicioara, Turnu Severin, SW. Romania & $44.6689^{\circ} \mathrm{N}-22.7599^{\circ} \mathrm{E}$ & Popescu et al., 2006 \\
\hline
\end{tabular}




\begin{tabular}{|c|c|c|c|c|c|c|}
\hline 32 & Zanclean, Early Pliocene & 5.3 & $\mathrm{p}$ & Malaga, S. Spain & $36.7197^{\circ} \mathrm{N}-4.4972^{\circ} \mathrm{W}$ & Suc, unpublished \\
\hline 33 & Zanclean, Early Pliocene & 5.3 & $\mathrm{p}$ & Site 654, W. Tyrrhenian Sea & $40.5793^{\circ} \mathrm{N}-10.6966^{\circ} \mathrm{E}$ & Popescu, unpublished \\
\hline 34 & Messinian, Late Miocene & 5.37 & $\mathrm{p}$ & Maccarone, Apiro, E. Italy & $43.4090^{\circ} \mathrm{N}-13.1042^{\circ} \mathrm{E}$ & Bertini, 1994 \\
\hline 35 & Early Pontian, Messinian, Late Miocene & 6 & $\mathrm{~m}$ & Kodor River, Kutaisi, Georgia & $42.2967^{\circ} \mathrm{N}-42.7164^{\circ} \mathrm{E}$ & Axelrod, 1975 \\
\hline 36 & Messinian, Late Miocene & 6 & $\mathrm{p}$ & Ifounassene, N. Morocco & $35.3270^{\circ} \mathrm{N}-2.9587^{\circ} \mathrm{E}$ & Bachiri Taoufiq, unpublished \\
\hline 37 & Messinian, Late Miocene & 6.2 & $\mathrm{p}$ & Carmona, SW. Spain & $37.4577^{\circ} \mathrm{N}-5.6502^{\circ} \mathrm{W}$ & Fauquette et al., 2006 \\
\hline 38 & Tortonian and Messinian, Late Miocene & $8-6$ & $\mathrm{p}$ & Capodarso, Enna, Sicily, S. Italy & $37.5167^{\circ} \mathrm{N}-14.1453^{\circ} \mathrm{E}$ & Suc et al., 1995 \\
\hline 39 & $\begin{array}{l}\text { Early Sarmatian, } \\
\text { Late Miocene }\end{array}$ & $10-9$ & $\mathrm{~m}$ & Bursuc, Moldavia & $47.9724^{\circ} \mathrm{N}-28.7414^{\circ} \mathrm{E}$ & Iamandei et al., 2005 \\
\hline 40 & Tortonian, Late Miocene & 11 & $\mathrm{p}$ & Well Andalucia A1, SW. Mediterranean & $36.5833^{\circ} \mathrm{N}-2.7166^{\circ} \mathrm{W}$ & Jiménez-Moreno \& Suc, 2007 \\
\hline 41 & $\begin{array}{l}\text { Serravallian-Tortonian, } \\
\text { Miocene }\end{array}$ & $12-11$ & $\mathrm{p}$ & Saouaf Basin, Tunisia & $36.2281^{\circ} \mathrm{N}-10.1717^{\circ} \mathrm{E}$ & $\begin{array}{l}\text { Ben Moktar \& Mannaï-Tayech, } \\
2012\end{array}$ \\
\hline 42 & $\begin{array}{l}\text { Serravallian-Tortonian, } \\
\text { Miocene }\end{array}$ & $12-11$ & $\mathrm{p}$ & Well Alborán A1, SW. Mediterranean & $36.6333^{\circ} \mathrm{N}-4.2230^{\circ} \mathrm{W}$ & Jiménez-Moreno \& Suc, 2007 \\
\hline 43 & $\begin{array}{l}\text { Early Sarmatian, } \\
\text { Mid-Miocene }\end{array}$ & 12.6 & $\mathrm{~m}$ & Dédestapolcsány, NE. Hungary & $48.1801^{\circ} \mathrm{N}-20.4850^{\circ} \mathrm{E}$ & Hably, 2006 \\
\hline 44 & $\begin{array}{l}\text { Serravallian, } \\
\text { Mid-Miocene }\end{array}$ & 13 & $\mathrm{~m}$ & Soma, W. Turkey & $37.8869^{\circ} \mathrm{N}-29.1434^{\circ} \mathrm{E}$ & Akgün et al., 2007 \\
\hline 45 & Langhian, Mid-Miocene & 14 & $\mathrm{p}$ & Gor, SE. Spain & $37.3766^{\circ} \mathrm{N}-2.9666^{\circ} \mathrm{W}$ & Jiménez-Moreno \& Suc, 2007 \\
\hline 46 & Langhian, Mid-Miocene & 15 & $\mathrm{p}$ & La Rierussa, Gelida, NE. Spain & $41.4527^{\circ} \mathrm{N}-1.8655^{\circ} \mathrm{E}$ & Jiménez-Moreno \& Suc, 2007 \\
\hline 47 & Lower Badenian, Mid-Miocene & 16 & $\mathrm{~m}$ & Szurdokpüspöki, N. Hungary & $47.8639^{\circ} \mathrm{N}-19.7154^{\circ} \mathrm{E}$ & Hably, 2006 \\
\hline 48 & Burdigalian, Early Miocene & 16 & $\mathrm{p}$ & V. Hugo College, Narbonne, S. France & $43.1880^{\circ} \mathrm{N}-3.0060^{\circ} \mathrm{E}$ & Bessedik et al., 1984 \\
\hline 49 & Burdigalian, Early Miocene & 17 & $\mathrm{p}$ & Estagel, Istres, S. France & $43.5187^{\circ} \mathrm{N}-4.9975^{\circ} \mathrm{E}$ & Jiménez-Moreno \& Suc, 2007 \\
\hline 50 & Burdigalian, Early Miocene & 17.5 & $\mathrm{p}$ & Rubielos de Mora, E. Spain & $40.1855^{\circ} \mathrm{N}-0.7913^{\circ} \mathrm{W}$ & Jiménez-Moreno et al., 2010 \\
\hline 51 & Ottnangian-Karpatian, Early Miocene & 18 & $\mathrm{~m}$ & Abaliget, S. Hungary & $46.1427^{\circ} \mathrm{N}-18.1143^{\circ} \mathrm{E}$ & Hably, 2006 \\
\hline 52 & Burdigalian, Early Miocene & 19 & $\mathrm{p}$ & Häutligen, Bern, Switzerland & $46.8572^{\circ} \mathrm{N}-7.6052^{\circ} \mathrm{E}$ & Jiménez-Moreno, 2005 \\
\hline 53 & Aquitanian, Early Miocene & 23 & $\mathrm{p}$ & Portel, S. France & $43.0519^{\circ} \mathrm{N}-2.9286^{\circ} \mathrm{E}$ & Bessedik, 1984 \\
\hline 54 & Aquitanian, Early Miocene & 23 & $\mathrm{~m}$ & Aix en Provence, SE. France & $43.5431^{\circ} \mathrm{N}-5.4317^{\circ} \mathrm{E}$ & De Saporta 1863 \\
\hline 55 & Early Oligocene & 30 & $\mathrm{~m}$ & Eleshnitsa, SW. Bulgaria & $41.8702^{\circ} \mathrm{N}-23.6189^{\circ} \mathrm{E}$ & Palamarev et al., 2000 \\
\hline
\end{tabular}




\section{References.}

Aharonovich, S., Sharon, G., \& Weinstein-Evron, M. (2014) Palybnological investigations at the Middle Palaeolithic site of Nahal Mahanayeem Outlet, Israel. Quaternary International, 331, 149-166.

Akgün, F., Kayseri, M. S., \& Akkiraz, M. S. (2007) Palaeoclimatic evolution and vegetational changes during the Late Oligocene-Miocene period in Western and Central Anatolia (Turkey). Palaeogeography, Palaeoclimatology, Palaeoecology, 253, 56-106.

Arambourg, C., Arenes, J., \& Depape, G. (1952) Sur deux flores fossiles quaternaires d'Afrique du Nord. Comptes Rendus de l'Académie des Sciences de Paris, 234, 128-130.

Asouti, E., Kabukcu, C., White, C. E., Kuijt, I., Finlayson, B., \& Makarewicz, C. (2015) Early Holocene woodland vegetation and human impacts in the arid zone of the southern Levant. The Holocene, 25, 1565-1580.

Axelrod, D. I. (1975) Evolution and biogeography of Madrean-Tethyan sclerophyll vegetation. Annals of the Missouri Botanical Garden, 62, 280-334.

Ben Moktar, N. \& Mannaï-Tayech, B. (2012) Reconstitution de la végétation et du climat durant le Miocène dans le bassin de Saouaf (Tunisie centro-nord-orientale). Geodiversitas, 34, 445-456.

Bertini, A. (1994) Messinian-Zanclean vegetation and climate in north-central Italy. Historical Biology, 9, 3-10.

Bessais, E., \& Cravatte, J. (1988) Les écosystèmes végétaux pliocènes de Catalogne méridionale. Variations latitudinales dans le domaine nord-ouest méditerranéen. Geobios, 21, 49-63.

Bessedik, M. (1984) The early Aquitanian and upper Langhian-lower Serravallian environments in the Northwestern Mediterranean region. Paléobiologie continentale, 14, 153-179.

Bessedik, M., Aguilar, J.-P., Cappetta, H., \& Michaux, J. (1984) Le climat du Néogène dans le sud de la France (Provence, Languedoc, Roussillon) d'après l'analyse des faunes (rongeurs, sélaciens) et des flores polliniques. Paléobiologie continentale, 14, 191-204.

Bottema, S., \& Sarpaki, A. (2003) Environmental change in Crete: a 9000-year record of Holocene vegetation history and the effect of the Santorini eruption. The Holocene, 13, 733-749.

Brenac, P. (1984) Végétation et climat de la Campanie du Sud (Italie) au Pliocène final d'après l'analyse pollinique des dépôts de Camerota. Ecologia mediterranea, 10, 207-216.

Combourieu-Nebout, N. (1990) Les cycles glaciaire-interglaciaire en région méditerranéenne de 2,4 à 1,1 Ma : analyse pollinique de la série de Crotone (Italie méridionale). Paléobiologie continentale, 17, 35-59.

Fauquette, S., Suc, J.-P., Bertini, A., Popescu, S.-M., Warny, S., Bachiri Taoufiq, N., Perez Villa, M.-J., Chikhi, H., Subally, D., Feddi, N., Clauzon, G., \& Ferrier, J. (2006) How much did climate force the Messinian salinity crisis? Quantified climatic conditions from pollen records in the Mediterranean region. Palaeogeography, Palaeoclimatology, Palaeoecology, 238, 281-301.

Feddi, N., Fauquette, S., \& Suc, J.-P. (2011) Histoire plio-pléistocène des écosystèmes végétaux de Méditerranée sud-occidentale: apport de l'analyse pollinique de deux sondages en mer d'Alboran. Geobios, 44(1), 57-69.

Fouache, E., Dalongeville, R., Kunesch, S., Suc, J.-P., Subally, D., Prieur, A., \& Lozouet, P. (2005) The Environmental Setting of the Harbor of the Classical Site of Oeniades on the Acheloos Delta, Greece. Geoarchaeology: An International Journal, 20, 285-302.

González-Sampériz, P., Valero-Garcés, B. L., \& Carrión, J. S. (2004) Was the Ebro valley a glacial refugium for temperate trees? Anales de Biologia, 26, 13-20.

Hably, L. (2006). Catalogue of the Hungarian Cenozoic leaf, fruit and seed floras from 1856 to 2005. Studia Botanica Hungarica., 37, 41-129.

Iamandei, S., Iamandei, E., Tusa, L., \& Obada, T. (2005) Sarmatian petrified wood within "Bursuc Flora"(Moldova Rep.). Acta Palaeontologica Romaniae, 5, 223-229.

Jahns, S. (2003) A late Holocene pollen diagram from the Megaris, Greece, giving possible evidence for cultivation of Ceratonia siliqua L. during the last 2000 years. Vegetation History and Archaeobotany, 12, 127130.

Jahns, S., \& van den Bogaard, C. (1998) New palynological and tephrostratigraphical investigations of two salt lagoons on the island of Mljet, south Dalmatia, Croatia. Vegetation History and Archaeobotany, 7, $219-234$.

Jiménez-Moreno, G. (2005) Utilización del análisis polínico para la reconstrucción de la vegetación, clima y estimación de paleoaltitudes a lo largo de arco alpino europeo durante el Mioceno (21-8 Ma). PhD thesis, University of Grenade and University Lyon 1, 312 p.

Jiménez-Moreno, G., Fauquette, S., \& Suc, J. P. (2010) Miocene to Pliocene vegetation reconstruction and climate estimates in the Iberian Peninsula from pollen data. Review of Palaeobotany and Palynology, 162, 403-415.

Jiménez-Moreno, G., \& Suc, J.-P. (2007) Middle Miocene latitudinal climatic gradient in Western Europe: evidence from pollen records. Palaeogeography, Palaeoclimatology, Palaeoecology, 253, 224-241.

Lebreton, V., Lartigot, A.-S., Karatsori, E., Messager, E., Marquer, L., \& Renault-Miskovsky, J. (2007) Potentiels et limites de l'analyse pollinique de spéléothèmes quaternaires: applications à la reconstitution de l'environnement végétal de l'homme préhistorique sur le pourtour nord-méditerranéen. Quaternaire, 18, 153174. 
Leroi-Gourhan, A. (1973) Les possibilités de l'analyse pollinique en Syrie et au Liban. Paléorient, 1(1), 39-47.

Leroi-Gourhan, A. (1980) Les analyses polliniques au Moyen-Orient. Paléorient, 6, 79-91.

Martín-Puertas, C., Valero-Garcés, B. L., Pilar Mata, M., González-Sampériz, P., Bao, R., Moreno, A., \& Stefanova, V. (2008) Arid and humid phases in southern Spain during the last 4000 years: the Zonar Lake record, Cordoba. The Holocene, 18, 907-921.

Melamed, Y. (2002) Chalcolithic and Hellenistic plant remains from cave V/49. Atiqot, 41, 101-108.

Meyer, F. G. (1980) Carbonized food plants of Pompeii, Herculaneum, and the Villa at Torre Annunziata. Economic Botany, 34, 401-437.

Neumann, F. H., Kagan, E. J., Schwab, M. J., \& Stein, M. (2007) Palynology, sedimentology and palaeoecology of the late Holocene Dead Sea. Quaternary Science Reviews, 26, 1476-1498.

Ntinou, M., Badal, E., Carrión, Y., Fueyo, J. L. M., Carrión, R. F., \& Mira, J. P. (2013) Wood use in a medieval village: the contribution of wood charcoal analysis to the history of land use during the 13th and 14th centuries a. d. at Pobla d'Ifach, Calp, Alicante, Spain. Vegetation History and Archaeobotany, 22, 115-128.

Núñez, D. R., de Castro, C. O., \& Martínez, A. A. (1988) Arqueobotánica y Paleoetnobotánica en el Sureste de España, datos preliminares. Trabajos de Prehistoria, 45, 317-334.

Ochando, J., Carrión, J.S., Blasco, R., Fernández, S., Amorós, G., Munuera, M., Sañudo, P., \& Peris, J.-F. (2019)

Silvicolous Neanderthals in the far West: the mid-Pleistocene palaeoecological sequence of Bolomor Cave

(Valencia, Spain). Quaternary Science Reviews, in press.

Palamarev, E., Kitanov, G., Staneva, K., \& Bozukov, V. (2000) Fossil flora from Paleogene sediments in the northern area of the Mesta Graben in the Western Rhodopes. II. Analysis and stratigraphic importance of the flora. Phytologia Balcanica, 6, 3-11.

Popescu, S.-M., Krijgsman, W., Suc, J.-P., Clauzon, G., Mărunțeanu, M., \& Nica, T. (2006) Pollen record and integrated high-resolution chronology of the early Pliocene Dacic basin (southwestern Romania). Palaeogeography, Palaeoclimatology, Palaeoecology, 238, 78-90.

Renault-Miskovsky, J., \& Girard, M. (1978) Analyse pollinique du remplissage pléistocène inférieur et moyen de la grotte du Vallonnet (Roquebrune-Cap-Martin, Alpes-Maritimes). Géologie Méditerranéenne, 5, 385-402.

Saporta, G. D. de (1863) Études sur la vegetation du sud-est de la France a l'époque Tertiaire. Première partie, V. Annales des Sciences Naturelles Botanique, 4th series, 19, 159-278.

Schroedter, T. M., \& Nelle, O. (2015) New insights into Mid-Holocene vegetation in the southern Marmara region: Charcoal from the Late Neolithic to Early Chalcolithic settlement site Aktopraklık, northwestern Turkey. Quaternary International, 366, 81-95.

Servera-Vives, G., Riera, S., Picornell-Gelabert, L., Moffa-Sánchez, P., Llergo, Y., Garcia, A., Mus-Amezquita, M., García-Álvarez, S., \& Trías, M. C. (2018) The onset of islandscapes in the Balearic Islands: A study-case of Addaia (northern Minorca, Spain). Palaeogeography, Palaeoclimatology, Palaeoecology, 498, 9-23.

Suc, J.-P., Popescu, S.-M., Fauquette, S., Bessedik, M., Jiménez-Moreno, G., Bachiri Taoufiq, N., Zheng, Z., \& Médail, F. (2018) Reconstruction of Mediterranean flora, vegetation and climate for the last 23 million years based on an extensive pollen dataset. Ecologia mediterranea, 44(2), 53-85.

Šoštarić, R. (2005) The development of postglacial vegetation in coastal Croatia. Acta Botanica Croatica, 64, 383-390.

Suc, J.-P., Violanti, D., Londeix, L., Poumot, C., Robert, C., Clauzon, G., Gautier, F., Turon, J.-L., Ferrier, J., Chikhi, H., \& Cambon, G. (1995) Evolution of the Messinian Mediterranean enviuronments: the Tripoli Formation at Capodarso (Sicily, Italy). Review of Palaeobotany and Palynology, 87, 51-79.

Van Zeist, W., Baruch, U., \& Bottema, S. (2009) Holocene palaeoecology of the Hula area, northeastern Israel. A Timeless Vale. Archaeological and Related Essays on the Jordan Valley in Honour of Gerrit Van Der Kooij on the Occasion of his Sixty-Fifth Birthday, edited by: Kaptijn, K. \& Petit, L. P., Leiden University Press, Leiden, 29-64.

Western, A. (1971) The ecological interpretation of ancient charcoals from Jericho. Levant, 3, 31-40.

Zapata, L., López-Sáez, J. A., Ruiz-Alonso, M., Linstädter, J., Pérez-Jordà, G., Morales, J., Kehl, M., \& PeñaChocarro, L. (2013) Holocene environmental change and human impact in NE Morocco: Palaeobotanical evidence from Ifri Oudadane. The Holocene, 23, 1286-1296. 


\section{G) Carob tree generation time}

The review of 28 publications of phylogeography conducted on tree species (Table S2.6) revealed an average generation time of 69 years and values ranging from 10 to 220 years, with sometimes various values for the same species (e.g. 25 and 100 years for olive tree). Assuming an age of maturity $(\alpha)$ of 10 years (the first fruits are observed for 7 years old carob trees in cultivation) the formula $\mathrm{T}=\alpha+[\mathrm{s} /$ $\lambda$-s)] (Cavenders-Bare et al 2011) allows to estimate the generation time in various demographic contexts. It gives a maximum generation time of 109 years for a stable population $(\lambda=1)$ and a high survival rate (0.99) and a minimum generation time of 18 years for an expanding population $(\lambda=1.01)$ and a low survival rate (0.90), leading to a median generation time of 64 years which is close to the average value from literature. We used this value to convert node ages in years ago.

Table S2.6. Generation times used for tree species in phylogeographical studies

\begin{tabular}{|c|c|c|}
\hline Taxa & Generation time in years & Reference \\
\hline Eight neotropical tree species & 50 & Barthe et al. 2017 \\
\hline Afzelia quanzensis & 150 & Jinga and Ashley 2018 \\
\hline Betula maximowicziana & 100 & Tsuda et al. 2015 \\
\hline Castanopsis fargesii & 25 & Sun et al. 2014 \\
\hline Euterpe globosa & 101 & Van Valen 1975 \\
\hline Juglans regia & $80-110$ & Pollegioni et al. 2017 \\
\hline Juniperus microsperma & 50 & Shang et al. 2014 \\
\hline Malus sylvestris & 7.5 & Cornille et al 2015 \\
\hline Myrceugenia correifolia & 5 & Perez et al. 2017 \\
\hline Neolitsea sericea & $10-30$ & Cao et al .2018 \\
\hline Two Nothofagus species & $30-50$ & Soliani et al. 2015 \\
\hline Olea europea & 100 & Besnard et al. 2013 \\
\hline Olea europea & 20 & Diez et al. 2015 \\
\hline Phoenix canariensis & 25 & Saro et al. 2015 \\
\hline Populus adenopoda & 40 & Fan 2018 \\
\hline Populus tremula & 15 & Ingvarssson 2008 \\
\hline Two Populus species & $20-60$ & Macaya-Sanz 2012 \\
\hline Prunus dulci & 50 & Delplancke et al. 2013 \\
\hline Prunus sibirica & 20 & Wang 2017 \\
\hline Quercus sub sec. Virentes & $120-220$ & Cavender-Bares 2011 \\
\hline Quercus cerris & $30-50$ & Bagnoli 2016 \\
\hline Quercus chrysolepis & 50 & Bemmels 2016 \\
\hline Two Quercus species & 80 & Yang 2016 \\
\hline Nine Quercus species & 50 & Ortego et al .2015 \\
\hline Two Quercus species & $50-220$ & San Jose-Maldia et al. 2017 \\
\hline Sequoiadendron giganteum & 300 & Dodd and DeSilva 2016 \\
\hline Taxus baccata & 100 & Mayol et al 2015 \\
\hline Xylocarpus granatum & 10 & Tomizawa 2017 \\
\hline
\end{tabular}

\section{References:}

Bagnoli, F., Tsuda, Y., Fineschi, S., Bruschi, P., Magri, D., Zhelev, P., ... \& Vendramin, G. G. (2016). Combining molecular and fossil data to infer demographic history of Quercus cerris: insights on European eastern glacial refugia. Journal of Biogeography, 43, 679-690.

Barthe, S., Binelli, G., Hérault, B., Scotti-Saintagne, C., Sabatier, D., \& Scotti, I. (2017). Tropical rainforests that persisted: inferences from the Quaternary demographic history of eight tree species in the Guiana shield. Molecular Ecology, 26, 1161-1174

Bemmels, J. B., Title, P. O., Ortego, J., \& Knowles, L. L. (2016). Tests of species-specific models reveal the importance of drought in postglacial range shifts of a Mediterranean-climate tree: insights from integrative 
distributional, demographic and coalescent modelling and ABC model selection. Molecular Ecology, 25, 48894906.

Besnard, G., Khadari, B., Navascués, M., Fernández-Mazuecos, M., El Bakkali, A., Arrigo, N., ... \& Savolainen, V. (2013). The complex history of the olive tree: from Late Quaternary diversification of Mediterranean lineages to primary domestication in the northern Levant. Proceedings of the Royal Society B: Biological Sciences, 280, 20122833.

Cao, Y. N., Wang, I. J., Chen, L. Y., Ding, Y. Q., Liu, L. X., \& Qiu, Y. X. (2018). Inferring spatial patterns and drivers of population divergence of Neolitsea sericea (Lauraceae), based on molecular phylogeography and landscape genomics. Molecular Phylogenetics and Evolution, 126, 162-172.

Delplancke, M., Alvarez, N., Benoit, L., Espindola, A., Joly, H. I., Neuenschwander, S., \& Arrigo, N. (2013). Evolutionary history of almond tree domestication in the Mediterranean basin. Molecular Ecology, 22, 10921104.

Diez, C. M., Trujillo, I., Martinez-Urdiroz, N., Barranco, D., Rallo, L., Marfil, P., \& Gaut, B. S. (2015). Olive domestication and diversification in the Mediterranean Basin. New Phytologist, 206, 436-447.

Dodd, R. S., \& DeSilva, R. (2016). Long-term demographic decline and late glacial divergence in a Californian paleoendemic: Sequoiadendron giganteum (giant sequoia). Ecology and Evolution, 6, 3342-3355.

Fan, L., Zheng, H., Milne, R. I., Zhang, L., \& Mao, K. (2018). Strong population bottleneck and repeated demographic expansions of Populus adenopoda (Salicaceae) in subtropical China. Annals of Botany, 121, 665679.

Ingvarsson PK (2008) Multilocus patterns of nucleotidepolymorphism and the demographic history of Populus tremula. Genetics, 180, 329-340

Jinga, P., \& Ashley, M. V. (2018). A mountain range is a strong genetic barrier between populations of Afzelia quanzensis (pod mahogany) with low genetic diversity. Tree Genetics \& Genomes, 14, 4.

Macaya-Sanz, D., Heuertz, M., López-de-Heredia, U., de-Lucas, A. I., Hidalgo, E., Maestro, C., ... \& González-Martínez, S. C. (2012). The Atlantic-Mediterranean watershed, river basins and glacial history shape the genetic structure of Iberian poplars. Molecular Ecology, 21, 3593-36

Mayol, M., Riba, M., González-Martínez, S. C., Bagnoli, F., Beaulieu, J. L., Berganzo, E., ... \& Romšáková, I. (2015). Adapting through glacial cycles: insights from a long-lived tree (Taxus baccata). New Phytologist, 208, 973-986.

Ortego, J., Noguerales, V., Gugger, P. F., \& Sork, V. L. (2015). Evolutionary and demographic history of the Californian scrub white oak species complex: an integrative approach. Molecular Ecology, 24, 6188-6208.

Pérez, F., Hinojosa, L. F., Peralta, G., Montenegro, P., Irarrázabal, C., \& Cossio, M. (2017). Genetic Patterns of Myrceugenia correifolia, a Rare Species of Fog-Dependent Forests of Mediterranean Chile: Is It a Climatic Relict? Frontiers in Plant Science, 8, 1097.

Pollegioni, P., Woeste, K., Chiocchini, F., Del Lungo, S., Ciolfi, M., Olimpieri, I., ... \& Malvolti, M. E. (2017). Rethinking the history of common walnut (Juglans regia L.) in Europe: Its origins and human interactions. PloS one, 12, $\mathrm{e} 0172541$.

San Jose-Maldia, L., Matsumoto, A., Ueno, S., Kanazashi, A., Kanno, M., Namikawa, K., ... \& Tsumura, Y. (2017). Geographic patterns of genetic variation in nuclear and chloroplast genomes of two related oaks (Quercus aliena and Q. serrata) in Japan: implications for seed and seedling transfer. Tree Genetics \& Genomes, 13, 121.

Saro, I., González-Pérez, M. A., García-Verdugo, C., \& Sosa, P. A. (2015). Patterns of genetic diversity in Phoenix canariensis, a widespread oceanic palm (species) endemic from the Canarian archipelago Tree Genetics \& Genomes, 11,815 .

Shang, H. Y., Li, Z. H., Dong, M., Adams, R. P., Miehe, G., Opgenoorth, L., \& Mao, K. S. (2015). Evolutionary origin and demographic history of an ancient conifer (Juniperus microsperma) in the QinghaiTibetan Plateau. Scientific Reports, 5, 10216.

Soliani, C., Tsuda, Y., Bagnoli, F., Gallo, L. A., Vendramin, G. G., \& Marchelli, P. (2015). Halfway encounters: Meeting points of colonization routes among the southern beeches Nothofagus pumilio and $N$. antarctica. Molecular Phylogenetics and Rvolution, 85, 197-207.

Sun, Y., Hu, H., Huang, H., \& Vargas-Mendoza, C. F. (2014). Chloroplast diversity and population differentiation of Castanopsis fargesii (Fagaceae): a dominant tree species in evergreen broad-leaved forest of subtropical China. Tree Genetics \& Genomes, 10, 1531-1539. 
Tomizawa, Y., Tsuda, Y., Saleh, M., Wee, A., Takayama, K., Yamamoto, T., ... \& Ardli, E. (2017). Genetic structure and population demographic history of a widespread mangrove plant Xylocarpus granatum J. Koenig across the Indo-West Pacific region. Forests, 8, 480.

Tsuda, Y., Nakao, K., Ide, Y., \& Tsumura, Y. (2015). The population demography of Betula maximowicziana, a cool-temperate tree species in Japan, in relation to the last glacial period: its admixture-like genetic structure is the result of simple population splitting not admixing. Molecular Ecology, 24, 1403-1418.

Van Valen, L. (1975). Life, death, and energy of a tree. Biotropica, 259-269.

Wang, Z., Zeng, Y., Zhang, Z., Sheng, S., Tian, J., Wu, R., \& Pang, X. (2017). Phylogeography Study of the Siberian Apricot (Prunus sibirica L.) in Northern China Assessed by Chloroplast Microsatellite and DNA Makers. Frontiers in plant science, 8, 1989.

Yang, J., Di, X., Meng, X., Feng, L., Liu, Z., \& Zhao, G. (2016). Phylogeography and evolution of two closely related oak species (Quercus) from north and northeast China. Tree Genetics \& Genomes, 12, 89. 


\section{APPENDIX S3 Extended results}

- Divergence time analysis

- Results of STRUCTURE HARVESTER

- Plot of admixture proportion from STRUCTURE analysis from $K=2$ to $K=10$ clusters

- Ward clustering tree based on Jost'D differentiations

- Genetic diversity map

- $\mathrm{ABC}$ parameter estimates and distributions

- $\mathrm{ABC}$ Posterior predictive simulations plots

- SDM maps for three Global Circulation Models 


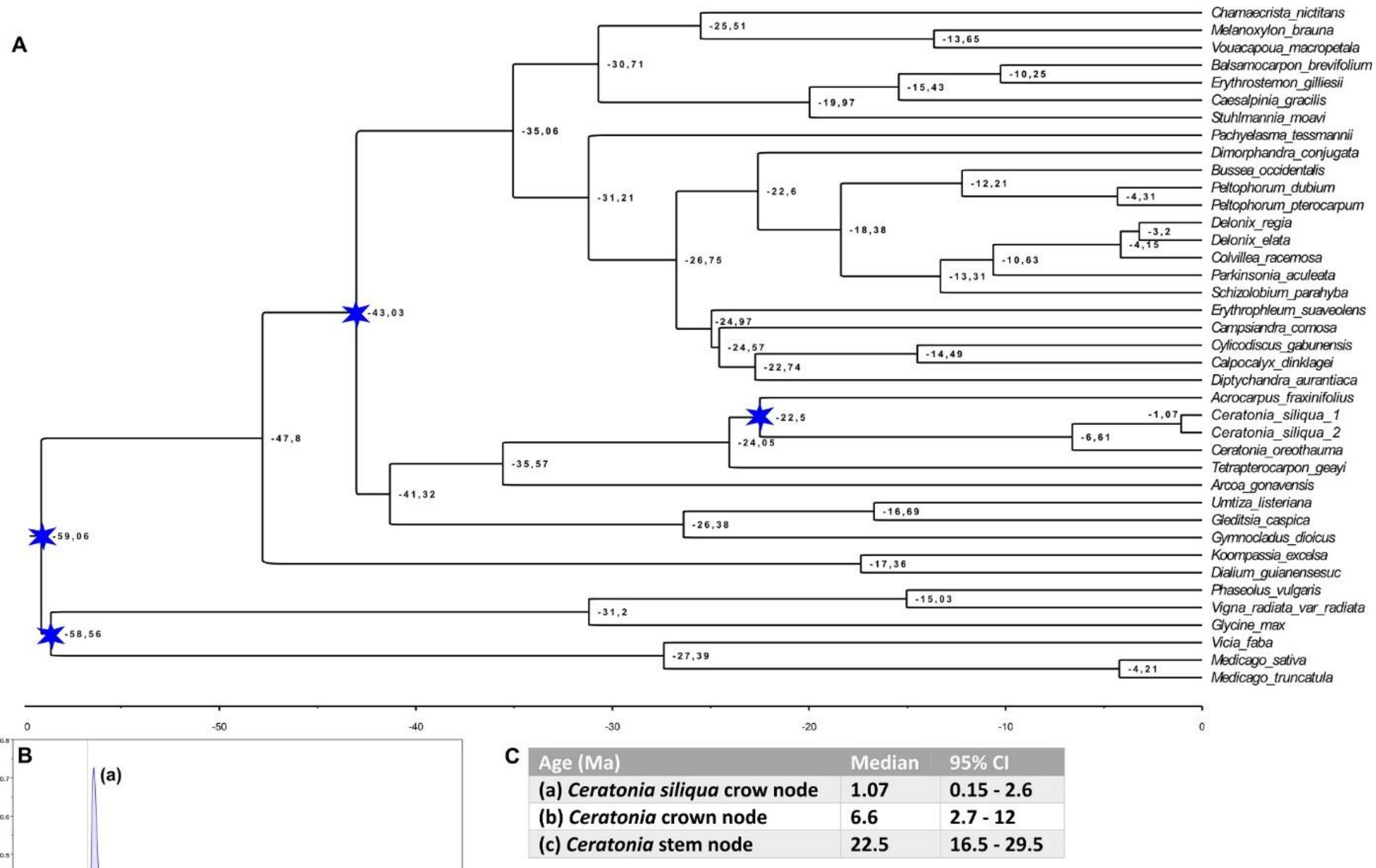

Figure S3.1: Divergence time estimates from BEAST analysis of a concatenated matrix of matK, SUSY 1 and 2 markers (two runs of $50 \mathrm{M}$ simulations). (A) Time tree, Calibrations were fixed for nodes indicated by a star. Ceratonia siliqua 1 and 2 are coming from Spain (Ojen) and Lebanon (Aramoun) and they are belonging to plastid haplogroup 1 and 2, respectively. (B) Ceratonia divergence time distributions. (C) Node ages medians and their $95 \% \mathrm{CI}$ 


\section{A) Structure analyses}

Table S3.1: Result of STRUCTURE HAVERSTER based on 10 replicates of STRUCTURE analysis for each K (2 000000 chain length after 200000 burn-in simulations by replicate).

\begin{tabular}{|c|c|c|c|c|c|c|}
\hline K Reps & & Mean LnP(K) & $\begin{array}{l}\text { Stdev } \\
\text { LnP(K) }\end{array}$ & $\operatorname{Ln}^{\prime}(\mathrm{K})$ & $|\operatorname{Ln} "(\mathrm{~K})|$ & Delta K \\
\hline 1 & 10 & $\begin{array}{l}38397.990000 \\
-\end{array}$ & 0.031623 & - & - & - \\
\hline 2 & 10 & $\begin{array}{l}37098.560000 \\
-\end{array}$ & 1.963670 & 1299.430000 & 668.610000 & 340.489995 \\
\hline 3 & 10 & $\begin{array}{l}36467.740000 \\
-\end{array}$ & 35.077096 & 630.820000 & 8.980000 & 0.256008 \\
\hline 4 & 10 & $\begin{array}{l}35845.900000 \\
-\end{array}$ & 5.846176 & 621.840000 & 275.990000 & 47.208634 \\
\hline 5 & 10 & $\begin{array}{l}35500.050000 \\
-\end{array}$ & 25.124766 & 345.850000 & 58.510000 & 2.328778 \\
\hline 6 & 10 & $\begin{array}{l}35212.710000 \\
-\end{array}$ & 46.442376 & 287.340000 & 9.200000 & 0.198095 \\
\hline 7 & 10 & $\begin{array}{l}34934.570000 \\
-\end{array}$ & 52.053883 & 278.140000 & 62.180000 & 1.194531 \\
\hline 8 & 10 & $\begin{array}{l}34718.610000 \\
-\end{array}$ & 43.083986 & 215.960000 & 8.880000 & 0.206109 \\
\hline 9 & 10 & $\begin{array}{l}34511.530000 \\
-\end{array}$ & 37.374086 & 207.080000 & 2.940000 & 0.078664 \\
\hline 10 & 10 & 34301.510000 & 57.785897 & 210.020000 & - & - \\
\hline
\end{tabular}



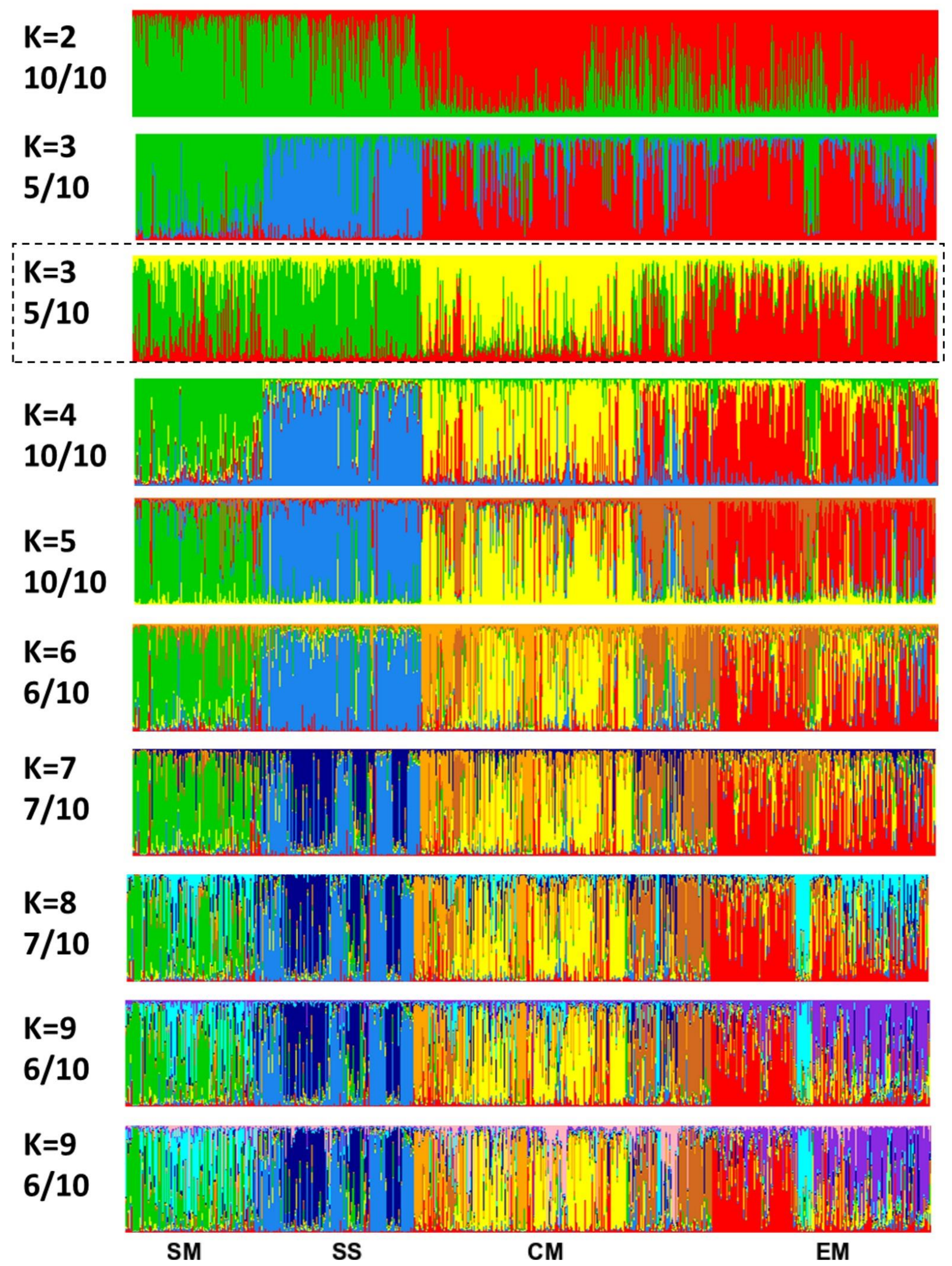

Figure S3.2. Admixture proportions inferred for 1037 carob genotypes from 67 provenances for $K=1$ to $K=10$ by 10 replicates of STRUCTURE (each 2000000 chain length after 200000 burn-in simulations, admixture model, no population prior) analyzed by CLUMPAK. For each $\mathrm{K}$ only the majority solution is shown with its support for 10 replicates, excepted for $\mathrm{K}=3$. The population are in the same order than in Figure 2. 


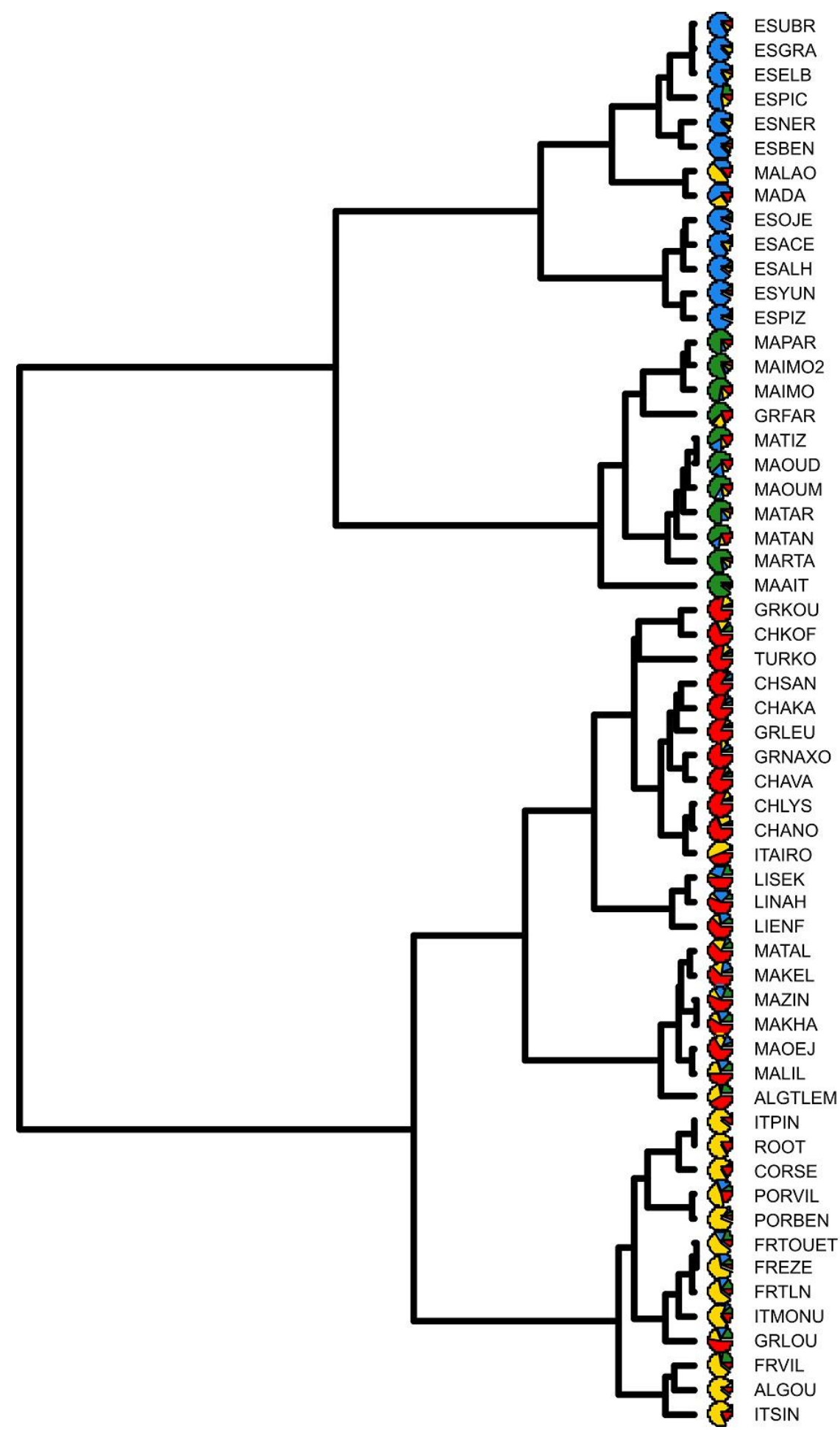

Figure S3.3. Clustering tree obtained with the Ward method and pairwise Jost's D differentiations between populations having at least 10 individuals. Population names are corresponding to locality names of Table S1.1. The pie charts are corresponding to admixture plots obtained with STRUCTURE for $\mathrm{K}=4$ groups. 


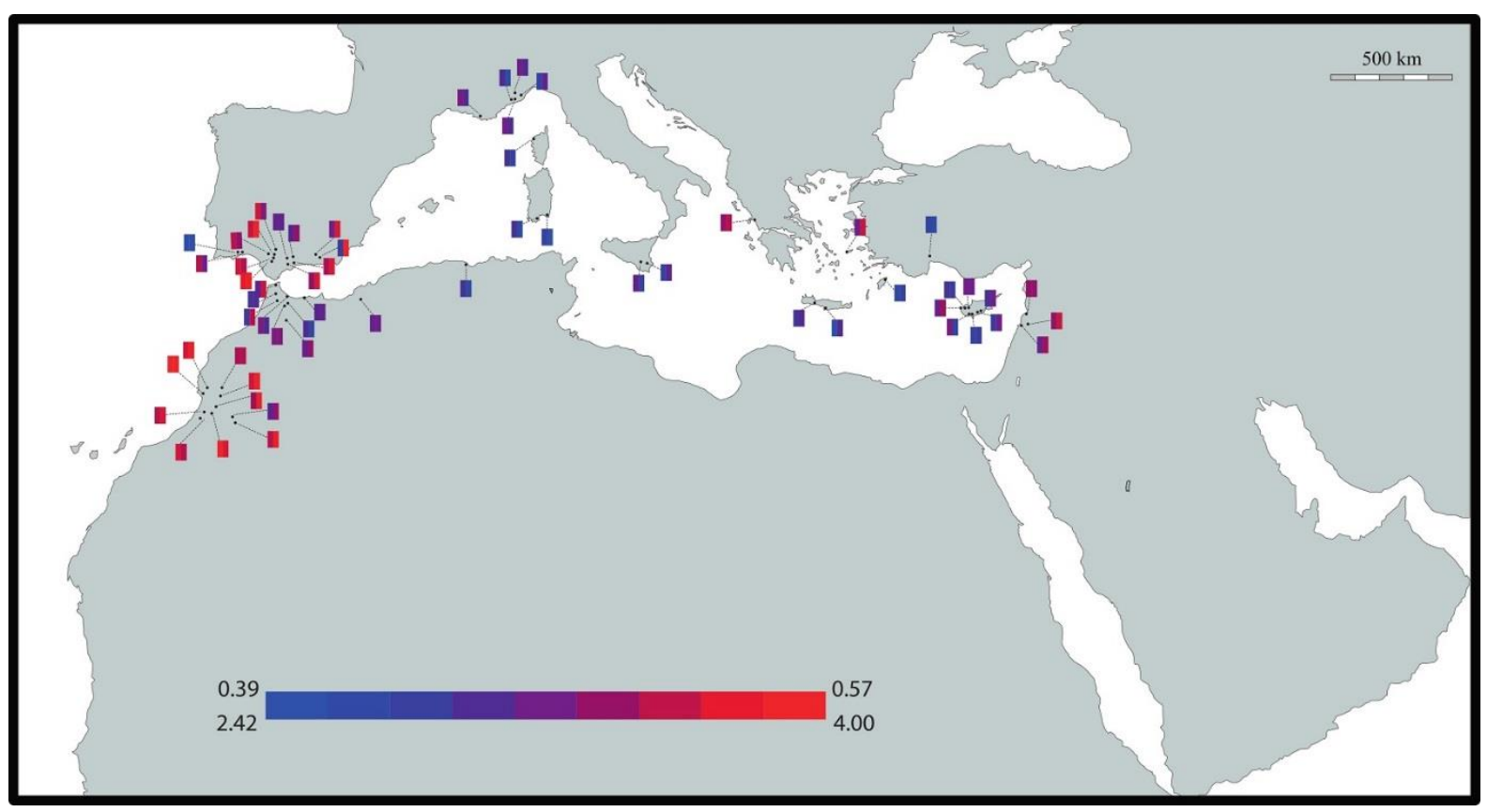

Figure S3.4: Genetic diversity scores per population of Ceratonia siliqua genotyped for 17 microsatellite loci, allelic richness on the left (from 2.42 to 4 ) and expected heterozygosity on the right. 
Table S3.2: Parameters inferred by the ABC neuralnet method for TRH model.

\begin{tabular}{lllllll}
\hline Parameter & Prior Range & Distribution & Meaning & \multicolumn{3}{c}{ Mode and 95\% HPD } \\
\hline & & & & $\mathbf{2 . 5 \%}$ & Mode & $\mathbf{9 7 . 5 \%}$ \\
T1 & $1-10,000$ & uniform & Divergence between SM and SS & 170 & 695 & 1,850 \\
T2 & $1-10,000$ & uniform & Divergence between EM and CM & 53 & 380 & 1,186 \\
Tanc & $1-10,000$ & uniform & Ancestral divergence & 400 & 1,815 & 4,640 \\
NSM & $10-10,000$ & uniform & Current effective size SM & 4,295 & 9,350 & 9,985 \\
NSS & $10-10,000$ & uniform & Current effective size SS & 2,460 & 5,840 & 9,990 \\
NCM & $10-10,000$ & uniform & Current effective size CM & 3,460 & 6,910 & 9,985 \\
NEM & $10-10,000$ & uniform & Current effective size EM & 3,145 & 7,245 & 9,990 \\
Nanc & $10-10,000$ & uniform & Ancestral effective size & 15 & 910 & 7,510 \\
mutssr & $0.0001-0.0008$ & loguniform & Mutation rate per locus & 1.0 E-04 & 1.9 E-04 & 3.0 E-04 \\
p & $0.1-0.3$ & loguniform & Parameter for the GSM model & 1.1 E-01 & 1.5 E-01 & 2.9 E-01 \\
\hline
\end{tabular}



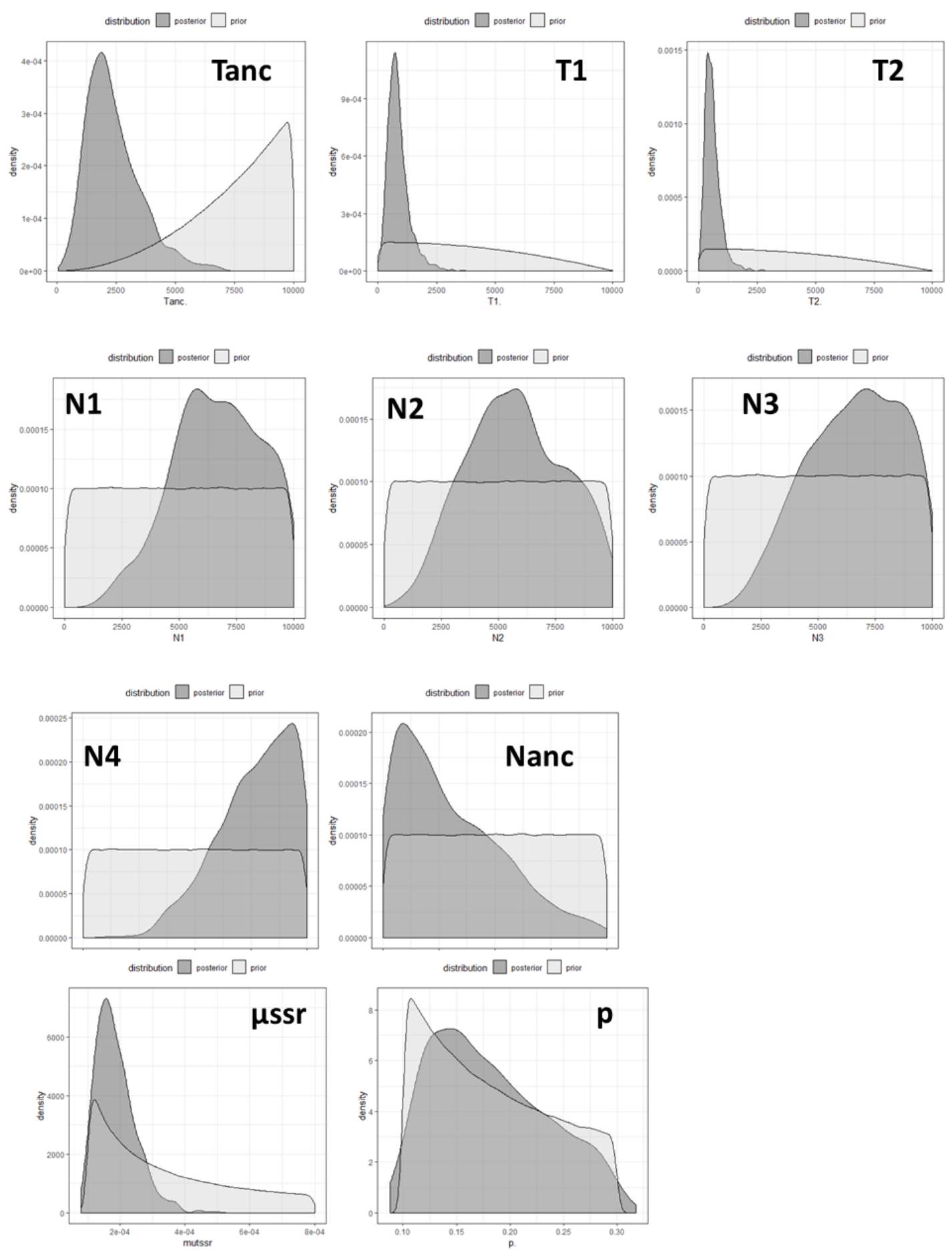

Figure S3.5: Parameter distributions obtained from model TRH. Prior and posterior in light and dark grey respectively. 

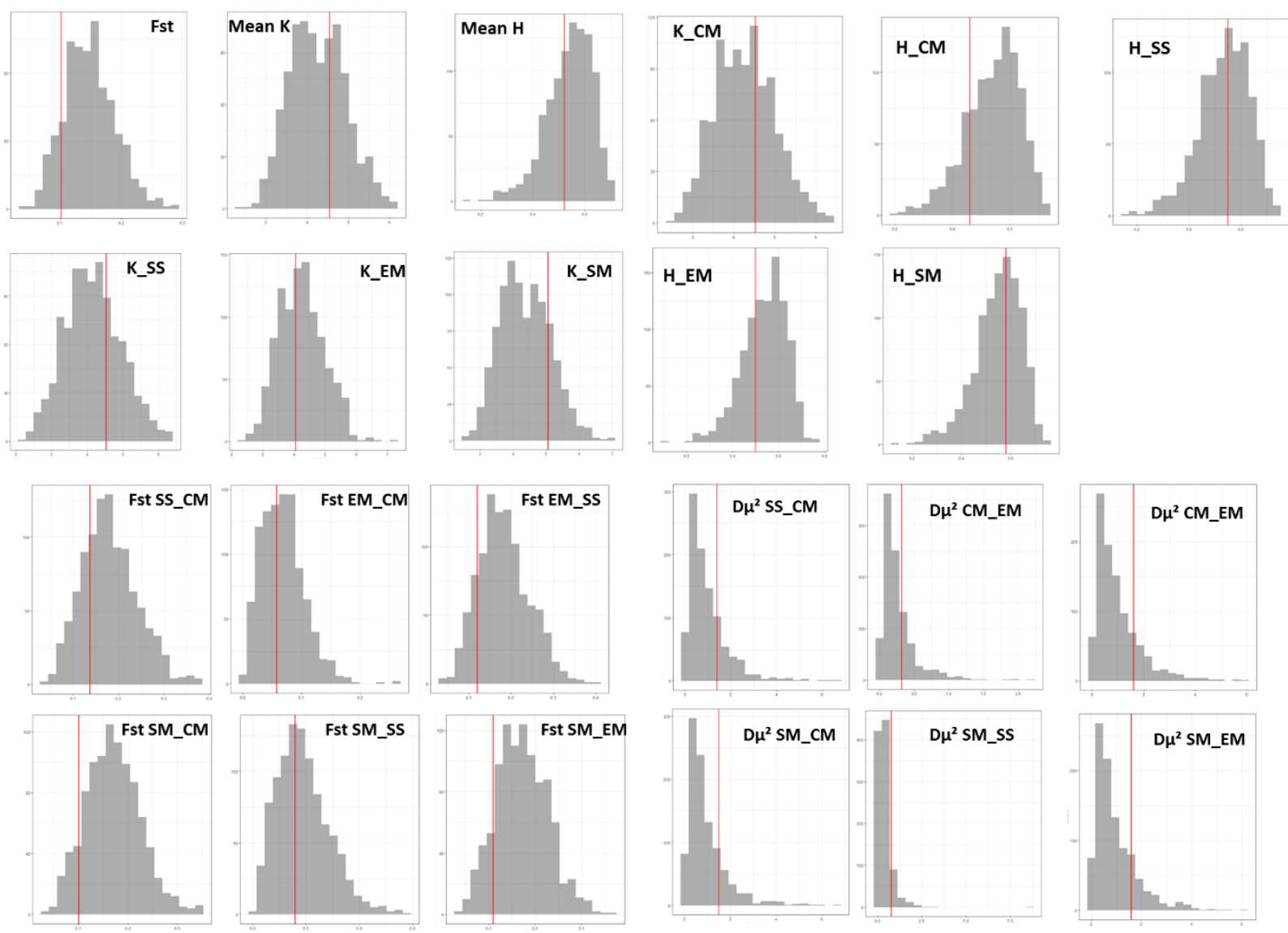

Figure S3.6: Posterior predictive simulations of the TRH model. Histograms show the distribution of 1,000 simulated values and the red vertical lines the observed value. 


\section{B) Environmental niche modelling}

Current

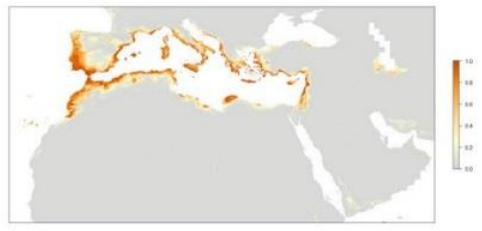

Mid-Holocene - ME

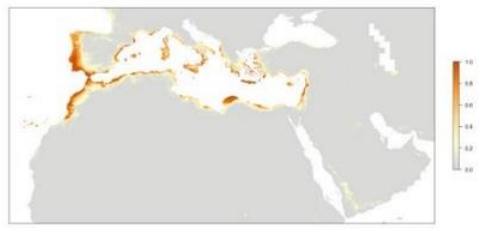

LGM - ME

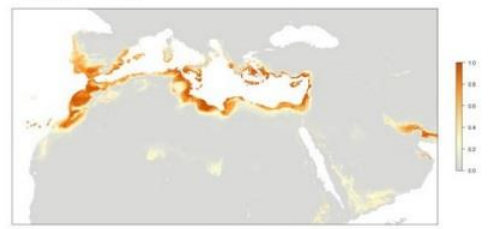

Mid-Holocene - CC

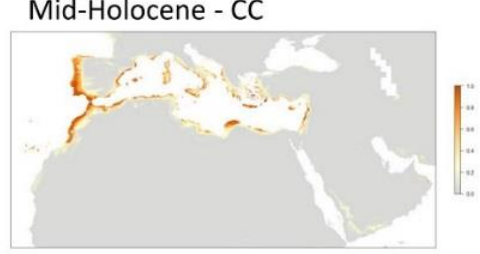

LGM - CC

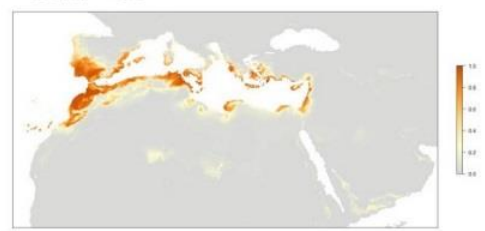

LIG

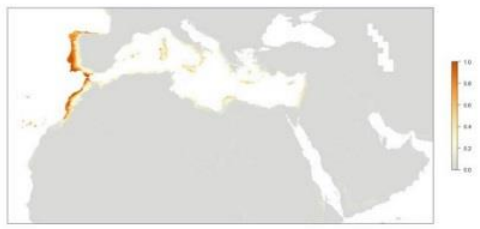

Mid-Holocene - MR

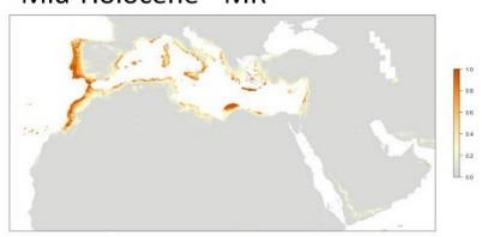

LGM - MR

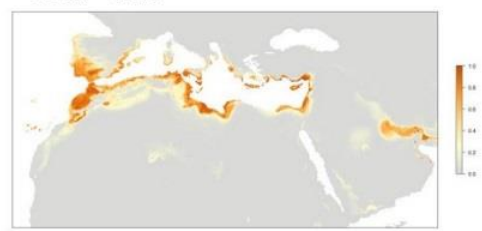

Figure S3.7: Species distribution modelling of the carob in four periods, for Mid-Holocene and LGM the results are presented for to three Global Circulation Models (GCMs); CCSM4 (CC), MIROC-ESM (MR), and MPI-ESM$\mathrm{P}(\mathrm{ME})$. 